1 Ethanol metabolites: Their role in the assessment of alcohol intake

Prof. Friedrich Martin Wurst ${ }^{\star 1,2}$, MSc. Natasha Thon ${ }^{\star 1}$, Dr. Michel Yegles ${ }^{3}$, MSc. Alexandra Schröck ${ }^{4}$, Prof. Ulrich W. Preuss ${ }^{5^{*}}$ Prof. Wolfgang Weinmann ${ }^{4^{*}}$ (1)

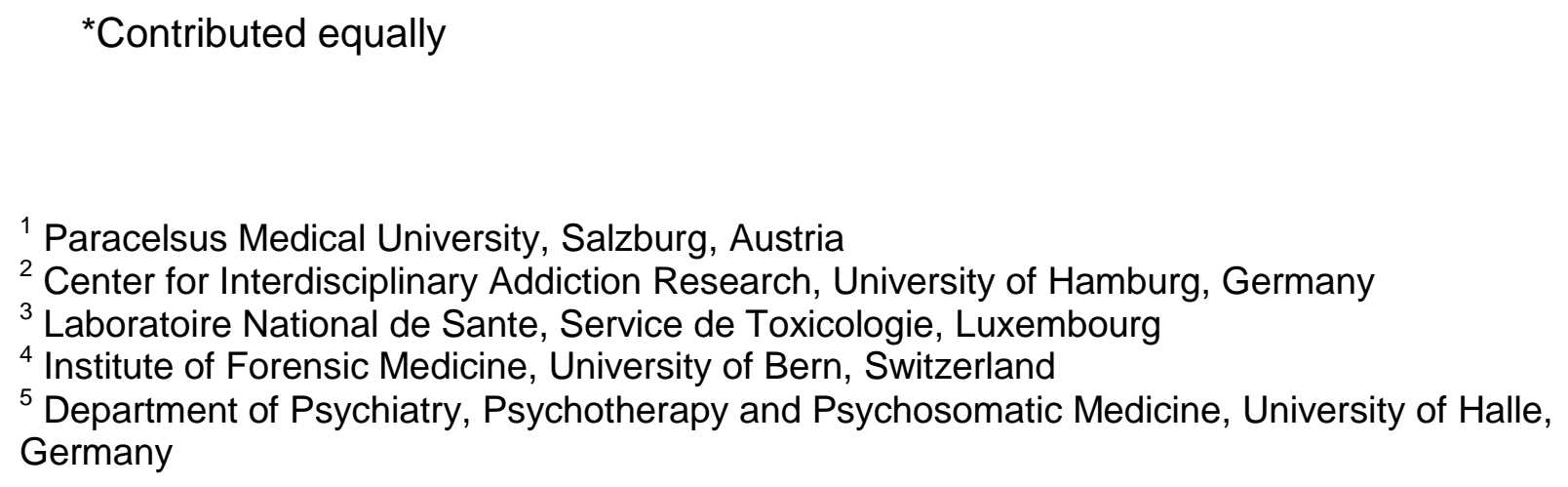


Abstract:

Background: Alcohol-related disorders are common, expensive in their course and often underdiagnosed. To facilitate early diagnosis and therapy of alcohol-related disorders and to prevent later complications, questionnaires and biomarkers are useful.

Methods: Indirect state markers like gamma-glutamyl-transpeptidase (GGT), mean corpuscular volume (MCV) and carbohydrate deficient transferrin (CDT) are influenced by age, gender, various substances and non-alcohol-related illnesses, and do not cover the entire timeline for alcohol consumption. Ethanol metabolites, such as ethyl glucuronide (EtG), ethyl sulphate (EtS), phosphatidylethanol (PEth) and fatty acid ethyl esters (FAEEs) have gained enormous interest in the last decades as they are detectable after ethanol intake.

Results: For each biomarker, pharmacological characteristics, detection methods in different body tissues, sensitivity/specificity values, cut-off values, time frames of detection and general limitations are presented. Another focus of the review is the use of the markers in special clinical and forensic samples.

54 Conclusion: Depending on the biological material used for analysis, ethanol metabolites can be applied in different settings such as assessment of alcohol intake, screening, prevention, diagnosis and therapy of alcohol use disorders.

Key words: alcohol intake, ethanol metabolites, ethyl glucuronide (EtG), phosphatidylethanol (PEth), ethyl sulphate (EtS), fatty acid ethyl esters (FAEEs) 
63

64

Introduction

Alcohol use disorders (AUD) cause approximately $4 \%$ of deaths worldwide - more than HIV, violence, or tuberculosis. In general hospitals, up to $20 \%$ of all inpatients have an alcohol use disorder. In surgical departments rates from $16 \%$ to $35 \%$ were described in patients with multiple trauma (Tonnesen \& Kehlet, 1999; Spies et al., 2001) leading to a number of unwanted consequences, including prolonged hospitalisation (Tonnesen \& Kehlet, 1999; Spies et al., 2001; Rubinsky et al., 2012), more time in Intensive Care Units and higher rates of complications (Rubinsky et al., 2012).

Of all alcohol-dependent individuals, $80 \%$ are treated by general practitioners, $34 \%$ in general hospitals and a low percentage by addiction specialists (Mann, 2002).

To facilitate early diagnosis and therapy of alcohol-related disorders and thus prevent secondary complications, questionnaires like the Alcohol Use Disorders Identification Test (AUDIT) (Saunders et al., 1993) as well as reliable and valid biomarkers are useful. Biomarkers have the advantage to indicate and reflect alcohol intake, independent of recall bias of the interviewed subjects.

Both indirect and direct state markers are routinely used to detect alcohol intake. The indirect state markers such as gamma-glutamyl-transpeptidase (GGT), mean corpuscular volume (MCV), and carbohydrate deficient transferrin (CDT) are influenced by a number of factors like age, gender, and non-alcohol-related illnesses, and do not cover the entire time frame (acute, short-term, long-term) of alcohol use (Conigrave et al., 2002; Laposata, 1999; Helander, 2003; Hannuksela et al., 2007; Niemelä, 2007).

Direct ethanol metabolites have gained interest in recent decades as they are biomarkers with high sensitivity and specificity. Most frequently, EtG (ethyl 
glucuronide) and PEth (phosphatidylethanol) are used in various settings and will

90 therefore be discussed in more detail.

\section{Ethanol metabolites}

93 Ethanol metabolites are formed after alcohol consumption and are minor pathways of ethanol elimination. They each cover different time frames of detection and can be determined in different matrices.

Routinely measured ethanol metabolites include:

- Ethyl glucuronide (EtG) in serum, whole blood, urine and hair

- Ethyl sulphate (EtS) in serum, whole blood and urine

- Phosphatidylethanol (PEth) in whole blood

102 Generally, ethanol metabolites are detectable in serum or whole blood for hours

103 (EtG, EtS), in urine for up to seven days (EtG, EtS), in whole blood over two weeks

104 (PEth) and in hair over months (EtG, FAEEs) (review by Thon et al 2014).

106 Ethyl glucuronide (EtG):

A. Pharmacology

108 Ethyl glucuronide (EtG) is a phase II metabolite of ethanol, has a molecular weight of

$109222 \mathrm{~g} / \mathrm{mol}$ and is is formed by the action of UDP-glucuronosyl transferase (Foti \&

110 Fisher, 2005). The possible effect of nutritional components such as flavonoids on

111 EtG formation is currently under investigation and seems to be a possible partial

112 explanation of the variability of EtG formation in humans (Schwab \& Skopp, 2014). 
113 Whereas the elimination of ethanol via glucuronidation is a minor pathway of alcohol

114 metabolism (less than $0.1 \%$ ) EtG is a valuable biomarker of ethanol intake. EtG is

115 non-volatile, water-soluble, and stable in storage. Depending on the amount of

116 consumed alcohol and time spent for consumption, EtG is still detectable in the body

117 long after completion of alcohol elimination (Schmitt et al., 1995, Wurst et al., 1999a,

118 2004; Dahl et al., 2002, 2011a; Borucki et al., 2005, Halter et al. 2008).

B. Specific body tissues, time frame and cut-off values

121 Based on a literature review, Walsham and Sherwood (2012) sum up that EtG can be

122 detected for up to 90 hours in urine. There is no difference regarding the elimination

123 rate between a healthy population and heavy alcohol consumers at the beginning of

124 detoxification treatment (Hoiseth et al., 2009).

125 EtG is also detectable in post-mortem body fluids and tissues like gluteal and 126 abdominal fat, liver, brain and cerebrospinal fluid (Wurst et al., 1999b), in bone 127 marrow, muscle tissue (Schlögel et al., 2005) and finger nails (Berger et al., 2013).

128 Even intake of small amounts of alcohol like $0.1 \mathrm{~L}$ champagne can be detected via

129 EtG for up to 27 hours. Experiments with $1 \mathrm{~g}$ ethanol (champagne, whisky) (Thierauf

130 et al., 2009) as well as use of mouthwash (Costantino et al., 2006) and hand 131 sanitizer gels (Rohrig et al., 2006) yielded ethyl glucuronide concentrations of less

132 than $1.0 \mathrm{mg} / \mathrm{L}$ in urine. Measurable concentrations in urine were found for up to 11

133 hours. This aspect is of relevance regarding unintentional exposure of alcohol:

134 pralines, non-alcoholic beer, pharmaceutical products, fruit juice, sauerkraut,

135 mouthwash products and hand sanitizer gels may contain small amounts of alcohol.

136 Even the intake of 21 - $42 \mathrm{~g}$ yeast with approximately $50 \mathrm{~g}$ sugar leads to

137 measureable EtG and EtS concentrations in urine (Thierauf et al., 2010). 
138 Inhalation of ethanol vapors may be another source for EtG in urine. Arndt et al.,

139 (2014a) emphasize that ethanol is mainly incorporated by inhalation not via the skin

140 by using hand sanitizers by hospital employees.

141 Therefore, a patients' claim not having consumed alcohol may be the truth even

142 when EtG is detectable in urine. Since patients in withdrawal treatment should avoid

143 even the smallest amount of alcohol, they have to be informed of such hidden

144 sources of ethanol to avoid unintentional alcohol intake. A differential cut-off of 0.1

$145 \mathrm{mg} / \mathrm{L}$ in cases where total abstinence is the goal, and $1.0 \mathrm{mg} / \mathrm{L}$ if small amounts of

146 alcohol intake are tolerated, have been recommended for practical reasons

147 (Costantino et al., 2006; SAMHSA 2012).

148 Based on the fact that exposure studies (by inhalation or disinfecting hands etc.) in

149 humans never yielded results above $1.0 \mathrm{mg} / \mathrm{L}$, a differential cut-off has been 150 suggested (Thierauf et al., 2009; SAMHSA 2012):

151 a) of $0.1 \mathrm{mg} / \mathrm{L}$ in cases where total abstinence is the goal

152 b) of $1.0 \mathrm{mg} / \mathrm{L}$ or more for EtG to confirm drinking.

153 c) In addition, a recent revision of the SAMHSA advisory suggests that values 154 between $0.5 \mathrm{mg} / \mathrm{L}$ and $1.0 \mathrm{mg} / \mathrm{L}$ could be from previous drinking as well as 155 from recent intense extraneous exposure within 24 hours or less.

156 For further details, see table 1.

158 Due to head hair growth of $1 \mathrm{~cm}$ per month, hair analysis allows a cumulative and 159 retrospective assessment of ethanol intake for a longer time period as compared to 160 blood and urine. In hair, hydrophilic EtG is incorporated through perspiration and/or 161 from blood (Pragst \& Yegles, 2007; Schräder et al 2012). 
162 For the assessment of chronic excessive alcohol consumption, EtG and FAEEs can

163 be used alone or in combination to increase the validity of hair analysis (Pragst \&

164 Yegles, 2008).

165 According to the consensus of the Society of Hair Testing (SOHT, 2014), a

166 concentration over $30 \mathrm{pg} / \mathrm{mg} \mathrm{EtG}$ in the $0-3 \mathrm{~cm}$ up to $0-6 \mathrm{~cm}$ proximal scalp hair

167 segment strongly suggests chronic excessive alcohol consumption.

168 For abstinence assessment HEtG should be the first choice, according to both the 169 consensus statement of the SOHT (2014) and a systematic review (Boscolo-Berto et

170 al., 2014). A concentration below $7 \mathrm{pg} / \mathrm{mg}$ does not contradict self-reported

171 abstinence of a person during the corresponding time period before sampling. A

$172 \mathrm{HEtG}$ concentration above $7 \mathrm{pg} / \mathrm{mg}$ in the $0-3 \mathrm{~cm}$ up to $0-6 \mathrm{~cm}$ proximal scalp hair

173 segment strongly suggests repeated alcohol consumption.

174 In an alcohol drinking experiment, 32 women, who consumed $16 \mathrm{~g}$ alcohol per day, 175 had EtG values of less than 7 pg in their scalp hair (Kronstrand et al., 2012). These 176 divergent results may be explained by the fact that EtG values lower than $7 \mathrm{pg} / \mathrm{mg}$ do 177 not exclude alcohol ingestion. Furthermore, scalp hair was cut pre-analytically in this 178 study while previous studies pulverised the specimen: The pre-analytical preparation, 179 such as washing, powdering (by a ball-mill) - or cutting by scissors in small pieces, 180 extraction by solvents with or without ultrasonication, has been reported to influence 181 the results significantly (Albermann et al., 2012a; Kummer et al., 2015; Mönch et al., 182 2013). These factors need some standardization, otherwise - as seen in proficiency 183 tests or other inter-laboratory tests, the precision of analysis is decreased.

A DRI ${ }^{\circledR}$ ethyl glucuronide enzyme immunoassay $\left(D R I^{\circledR}-E t G ~ E I A\right)$ is commercially

187 available. The first study showed satisfying but not convincing results (Böttcher et al., 
2008). Therefore, enquiries with medico-legal relevance need further confirmation with forensic-toxicologically acceptable methods like liquid chromatography - tandem mass spectrometry (LC-MS/MS (Weinmann et al., 2004).

191

D. Limitations

In recent years, the potential in vitro formation and degradation of EtG and EtS have gained attention (Helander et al., 2005; 2009; Baranowski et al., 2008; Halter et al., 2009). Initially, hydrolysis of EtG caused by microbes in urinary tract infections, especially E.coli, was reported (Helander et al., 2005). Baranowski et al (2008) confirmed complete degradation of EtG within 3 to 4 days by E.coli and C. sordellii. In contrast, the stability of EtS for up to 11 days was shown (Baranowski et al., 2008).

Furthermore, Hernandez Redondo et al. (2013) reported that the bacterial degradation of EtG by E. coli can be prevented by use of dried urine on filter paper.

The WHO/ISBRA Study showed that EtG urine concentrations are influenced by age, gender, cannabis consumption and renal function. In contrast, race, nicotine consumption, body mass index, liver cirrhosis and body water content had no significant influence on EtG concentrations (Wurst et al., 2004a). The results concerning renal and liver functions have recently been confirmed by two studies, one in which EtG elimination was prolonged for 14 patients with reduced renal function (Hoiseth et al., 2013), and another study in which severity of liver disease had no influence on the validity of EtG as a marker of alcohol use (Stewart et al 2013).

The positive predictive values of EtG for patients, who claimed abstinence in the last 3 days, were $81 \%$. The negative predictive values were $91 \%$. Had the patients claimed abstinence in the last 7 days, the positive predictive values would be $97 \%$, 
213 the negative predictive values would be $85 \%$ (Stewart et al., 2013, see also table 2a 214 and b).

215 Only single cases of false positive results for EtG in hair were found after use of EtG 216 containing herbal lotions (Sporkert et al., 2012; Arndt et al., 2013). Impaired kidney 217 function may lead to higher HEtG levels, as preliminary results indicate (Hoiseth et al. 218 2013).

219 The concentration of EtG in hair can be influenced by cosmetic treatments and 220 thermal hair straightening tools (Ettlinger et al., 2014). Bleaching, perming and dying 221 of hair may lead to lower concentrations of EtG or false-negative results (Yegles et 222 al., 2004; Kerekes \& Yegles, 2013; Morini et al., 2010a; Agius, 2014; Suesse et al., 223 2012).

224 The type of cosmetic hair treatment should be documented during sampling and 225 considered during interpretation. EtG appears not to be influenced by ethanol226 containing hair care products, whereas their use may lead to false positive FAEEs 227 (Hartwig et al., 2013; Suesse et al., 2012; Gareri et al., 2011).

228 In contrast to hair analysis for drugs and medication, hair colour and melanin content 229 in hair have no influence on HEtG (Kulaga et al., 2009; Appenzeller et al., 2007a). 230 Also for gender no effect on HEtG concentration have been reported (Crunelle et al., $2312014 a)$. In segmental investigations of hair samples, a chronological correlation to 232 drinking or abstinent phases was reported for HEtG by two studies (Wurst et al., 233 2008c; Appenzeller et al., 2007b), however not for FAEEs (Auwärter et al., 2004). 234 Only for HEtG a correlation was found in 3 studies between the EtG content in hair 235 and the amount of EtOH consumed (Appenzeller et al., 2007b; Crunelle et al., 2014b; 236 Politi et al., 2006). Altogether, hair analysis is a useful tool to estimate overall ethanol 237 intake over a longer time. 


\section{Ethyl sulphate (EtS)}

A. Pharmacology

241 Ethyl sulphate (EtS) has a molecular weight of $126 \mathrm{~g} / \mathrm{mol}$, and represents, like EtG, a

242 secondary elimination pathway for alcohol. EtS is detectable in varying inter-

243 individual concentrations (Dresen et al., 2004; Helander and Beck, 2004; Wurst et al.,

244 2006, Halter et al., 2008). An immunochemical detection test is currently not

245 commercially available for EtS. For combined detection of EtS and EtG, use of rapid

246 LC-MS/MS procedures is routinely applied.

247 EtS formation is catalyzed by the enzyme sulpho-transferase and the breakdown by 248 sulphatases.

B. Specific body tissues, time frame and cut-off values

251 EtS is detectable in the same body tissues as EtG. A cut-off of $0.05 \mathrm{mg} / \mathrm{L}$ for 252 repeated alcohol intake was suggested (Albermann et al., 2012b). As for ethyl 253 glucuronide, there is evidence of prolonged elimination in reduced renal function 254 (Hoiseth et al., 2013).

C. Methodical aspects

257 Schneider and Glatt (2004) developed a liquid chromatography-tandem-mass spectrometry method with 2-propylsulphates as internal standard. Helander and Beck (2004) used liquid chromatography-electro spray-ionisation-mass spectrometry (LC-

ESI-MS) in a single-quadruple-modus and $D_{5}$-ethyl sulfate as internal standard for the 261 quantification of EtS in urine samples. The disadvantage of this method is a longer 262 period of chromatographic separation. Furthermore, the exclusive monitoring of de263 protonated molecules in a single-MS does not meet forensic standards (Aderjan et 264 al., 2000; SOFT/AAFS, 2006). At any rate, an additional fragment ion would be 
265 required for the verification analyses according to forensic guidelines (SOFT/AAFS, 266 2006). Even when this requirement from forensic guidelines does not need to be met 267 in clinical diagnostics, it is still in demand in workplace drug testing in the USA. In this 268 context, a LC-MS/MS method with penta-deuterium EtS as internal standard and two 269 ion transitions (Dresen et al., 2004) raises particular interest, and can be used in 270 forensic and medico-legal cases as well as in clinical routine (Skipper et al., 2004).

D. Limitations:

273 In contrast to the above-described potential of in vitro formation and degradation of 274 EtG caused by microbes, Baranowski et al. showed the stability of EtS for up to 11 275 days (Baranowski et al., 2008). Further studies with standardized test procedures for 276 biodegradation showed that EtS in closed bottle test (OECD $301 \mathrm{D})$ remained stable 277 for even longer periods whereas in the context of a higher bacterial density such as in 278 the Manometric Respiratory Test (MRT) a reduction after 6 days was detected (Halter 279 et al., 2009). This problem could be countered by cooling and the addition of 280 stabilizers.

281 The positive predictive value of EtS for patients, who claimed abstinence in the last 3 282 days, was $70 \%$. The negative predictive values were $93 \%$. Had the patients claimed 283 abstinence in the last 7 days, the positive predictive values would be $80 \%$ 284 respectively, the negative predictive values would be $85 \%$ (Stewart et al., 2013, see 285 also table $2 a$ and $b$ ).

287 Fatty acid ethyl esters (FAEEs)

288 A. Pharmacology

289 In recent years, the existence of fatty acid ethyl esters (FAEEs), non-oxidative 290 metabolic products of ethanol in blood and various organs with reduced or deficient 
291 capacity to oxidize ethanol after consumption has been shown. Since these esters

292 have proven to cause damage to sub cellular structures, they were postulated to be 293 mediators of organ damage.

294 Two enzymes catalyse the formation of FAEEs: acyl-coenzyme a-ethanol o295 acyltransferase (AEAT) and fatty acid ethyl ester-synthase. Furthermore, pancreatic 296 lipase, lipoprotein lipase and glutathione transferase were shown to possess FAEE297 synthase activity (Tsujita \& Okuda, 1992; Bora et al., 1989; 1996).

298 Fatty acid ethyl esters are formed in the presence of ethanol from free fatty acids, 299 triglycerides, lipoproteins or phospholipids.

Detectable FAEE levels are found in blood shortly after alcohol consumption and remain positive for more than 24 hours (Borucki et al., 2005).

304 Regarding hair analyses, the deposit of lipophilic FAEEs occurs in sebum (Auwärter et al., 2004). A FAEE cut-off concentration of $0.5 \mathrm{ng} / \mathrm{mg}$ for the sum of the four esters 306 in scalp hair is considered strongly suggestive of chronic excessive alcohol 307 consumption when measured in the $0-3 \mathrm{~cm}$ proximal segment. If the proximal $0-6$ $\mathrm{cm}$ segment is used the proposed cut-off concentration is $1.0 \mathrm{ng} / \mathrm{mg}$ scalp hair.

309 The combined use of FAEEs and EtG (see above) can be recommended to increase 310 the validity of hair analysis (Pragst \& Yegles, 2008).

C. Methodical aspects

313 Of 15 different FAEEs in hair the sum of four (ethyl stearate, ethyl oleate, ethyl 314 myristate and ethyl palmitate) are shown to function as a marker in hair analysis 315 (Pragst \& Yegles, 2007). With a cut-off of $0.5 \mathrm{ng} / \mathrm{mg}$, a sensitivity and a specificity of $31690 \%$ were reported. A differentiation between abstinent, social and excessive 
317 drinkers seems possible (Yegles et al., 2004; Gonzalez-Illan, et al., 2011). However, 318 the complex GC/MS method lacks practicability for routine use.

D. Limitations:

321 Regarding hair samples, the analysis of FAEEs alone is not recommended to

322 determine abstinence from ethanol, but may be used in cases of suspected false 323 negative HEtG results, utilising a FAEEs cut-off concentration of $0.2 \mathrm{ng} / \mathrm{mg}$ for a 0 - 3 $\mathrm{cm}$ proximal scalp hair segment or $0.4 \mathrm{ng} / \mathrm{mg}$ for a $0-6 \mathrm{~cm}$ proximal scalp hair 325 segment.

326 The concentration of FAEEs in hair can be influenced by cosmetic treatments and 327 thermal hair straightening tools (Ettlinger et al., 2014). Regular use of alcohol328 containing hair tonic can lead to false positive FAEEs results (Hartwig et al., 2003). No such false positive results are reported for HEtG (Ferreira et al., 2012).

Phosphatidylethanol (PEth)

A. Pharmacology

334 Phosphatidylethanol (PEth), a phospholipid, is formed in the presence of alcohol via 335 the action of the enzyme phospholipase-D (PLD) (Alling et al., 1983). The precursors 336 are naturally existing phosphatidylcholine (PC) homologues. PEth consists of glycerol 337 which is substituted at positions sn1 and sn2 by fatty acids and is esterified in sn3 338 position with phosphoethanol (Gustavsson and Alling, 1987; Gnann et al., 2010; 339 Isaksson et al., 2011; (Kobayashi and Kanfer, 1987). Due to the variations of the fatty 340 acids, various homologues of PEth can be detected. In 2010, 48 PEth homologues 341 were described in the blood of a deceased alcohol-dependent individual for the first 
342 time (Gnann et al., 2010). The PEth homologues 16:0/18:1 und 16:0/18:2 are most

343 prevalent in human blood (Gnann et al., 2014) and their combined sum correlates

344 better with total PEth than PEth 16:0/18:1 or PEth 16:0/18:2 alone (Zheng et al., 345 2011).

346 PEth is formed directly after ingestion of alcohol (Gnann et al., 2012), but has a slow 347 elimination rate with a half-life time of approximately 4 days (Hannuksela et al., 348 2007). Therefore, PEth is a promising biomarker for the detection of alcohol abuse, 349 as it can be determined in blood of alcohol abusers even up to 3 weeks after 350 withdrawal (Viel et al., 2012; Winkler et al., 2013). Using the original high 351 performance liquid chromatography (HPLC) methods in combination with evaporative 352 light scattering detection (Varga et al., 1998; (Aradottir and Olsson, 2005)), repeated 353 consumption of more than $50 \mathrm{~g}$ alcohol over 2 - 3 weeks yielded positive results 354 (Varga et al., 1998), lately even with daily consumption over $40 \mathrm{~g}$ (Aradóttir et al., 355 2004).

356 Whereas before 2009 the HPLC method was used, later studies employed LC357 MS/MS.

B. Specific body tissues, time frame, cut-off values

With the LC-MS/MS approach single consumption of ethanol up to a blood alcohol 361 concentration (BAC) of approximately $0.1 \mathrm{~g} / \mathrm{dL}$, yielded PEth 16:0/18:1 362 concentrations up to approx. $120 \mathrm{ng} / \mathrm{mL}(0.17 \mu \mathrm{mol} / \mathrm{L})$ (Schröck et al., 2014) in whole 363 blood. A recent drinking experiment with healthy persons with an alcohol 364 consumption of $0.1 \mathrm{~g} / \mathrm{dL}$ on 5 consecutive days yielded PEth values up to $237 \mathrm{ng} / \mathrm{mL}$ 365 (0.32 $\mu \mathrm{mol} / \mathrm{L})$ (Gnann et al., 2012). In contrast, in alcohol-dependent patients, the 366 values were reported to be up to $4200 \mathrm{ng} / \mathrm{mL}$ (6 $\mu \mathrm{mol} / \mathrm{L})$ (Helander and Zheng, 2009), 367 whereas total PEth concentrations of more than $500 \mathrm{ng} / \mathrm{mL}(0.7 \mu \mathrm{mol} / \mathrm{L})$ have been 
368 considered as typical for prolonged alcohol misuse (Isaksson et al., 2011). In 2013, 369 Swedish laboratories suggested a cut-off for the PEth homologue 16:0/18:1 of 210 $370 \mathrm{ng} / \mathrm{mL}(0.3 \mu \mathrm{mol} / \mathrm{L})$ to differentiate between moderate drinking and alcohol misuse 371 (Helander and Hansson, 2013).

372 Various studies found no false positive PEth results (Wurst et al., 2003b, 2004; 373 Hartmann et al., 2007). A linear relationship between consumed amounts of alcohol 374 with phosphatidylethanol values has been described (Aradottir et al., 2006; Stewart et 375 al., 2009; Stewart et al., 2010).

376 In 144 patients, Aradottir et al. (2004) reported sensitivity of PEth to be $99 \%$, of CDT, 377 MCV and GGT to be between $40-77 \%$, as well as a correlation between the 378 amount consumed and the PEth value. In a receiver operating characteristic (ROC) 379 curve analysis with consumption status (active drinkers vs abstinent drinkers), as a 380 state variable and with PEth, MCV and GGT as test variables, an area under the 381 curve (AUC) of 0.973 for PEth could be found, the sensitivity was $94.5 \%$ and the 382 specificity $100 \%$ (Hartmann et al., 2007).

383 These findings were confirmed in subsequent publications (Wurst et al., 2010; 2012; 384 Stewart et al., 2010; Hahn et al., 2012). Furthermore, liver disease and hypertension 385 (Stewart et al., 2009; 2014) showed no influence on PEth values.

386 PEth has been employed in various settings including judging driving ability (Marques 387 et al, 2010; 2011), forensic psychiatry (Wurst et al., 2003b), monitoring programs 388 (Skipper et al., 2013), identification of alcohol intake in specific risk groups (Hahn et 389 al., 2012) and for neonatal screening of prenatal alcohol exposure (Bakhireva et al., 390 2013, Bakhireva et al., 2014). 
393 Concerning the interpretation of results, it is important to acknowledge that 394 publications before 2009 used the HPLC method in combination with evaporative 395 light scattering detection. This method detects the sum of all PEth homologues. In 396 contrast, new approaches use LC-MS, LC-MS/MS and on-line extraction LC-MS/MS 397 methods (Schrock et al., 2014). These methods allow the detection and quantification 398 of single homologues (Gnann et al., 2009), if a reference standard is available. 399 Furthermore, recent publications suggested LC-HRMS (Liquid Chromatography High 400 Resolution Mass Spectrometry) method (Nalesso et al., 2011) and a metabolic 401 approach using LC-MS-IT-TOF (Liquid Chromatography with Quadruple Ion Trap 402 Time-of-Flight-Mass Spectrometry) (Loftus et al., 2011). For everyday practical 403 application, the use of dried blood spots (DBS) may be of significant relevance (Faller 404 et al., 2013). This method is suggested to provide results similar to whole blood 405 analysis. Studies of PEth analysis on DBS showed good robustness and the 406 advantage that neo-formation of PEth in the presence of a positive BAC does not 407 occur after drying the blood on filter paper (Schrock et al., 2014). Furthermore, 408 obtaining specimens is simplified since non-medical staff can collect capillary blood, 409 also storage and transport are simplified, and the risks for HIV and hepatitis C 410 infections are decreased (Faller et al., 2013). D. Limitations

413 PEth concentrations were shown to be stable in blood samples stored in refrigerators $414\left(2-8^{\circ} \mathrm{C}\right)$ and when frozen at $-80^{\circ} \mathrm{C}$. However, decrease in PEth concentrations was 415 observed during storage at $-20^{\circ} \mathrm{C}$. When ethanol was present in samples, neo416 formation of PEth has been observed (Aradottir et al., 2004).

417 In-vitro formation of PEth in erythrocytes has been reported after addition of ethanol 418 (Varga and Alling, 2002). For further details see table 2a and table 2b. 


\section{II: Practical use in specific patient's samples and settings:}

421 EtG:

Practical use in specific patient's samples and settings:

1) Opioid maintenance therapy patients as specific high-risk group:

424 Many patients in opioid-maintenance therapy suffer from Hepatitis C (HCV) infection. Alcohol consumption, especially in large amounts, leads to the progression of cirrhosis (Gitto et al., 2009; Safdar \& Schiff, 2004). One study in Australia (Wurst et al., 2008a) and one in Switzerland (Wurst et al., 2011) showed the usefulness and necessity of the determination of ethyl glucuronide in patients in opioid-maintenance therapy. In the former study, $42 \%$ ( $n=8$ of 19) of all EtG positive patients would have not reported the alcohol consumption (Wurst et al., 2011). In the latter one, 75

$431 \%$ consumed alcohol according to the hair analysis for EtG, however, two thirds did 432 not report about it (Wurst et al., 2011).

433 The use of direct ethanol metabolites in high-risk groups therefore allows more 434 possibilities for therapeutic interventions, consequently leading to an improvement in 435 the quality of life.

436 2) Monitoring and rehabilitation programs:

437 a) One example for using ethyl glucuronide successfully in monitoring programs are 438 the Physician Health Programmes in the USA which provide a non-disciplinary 439 therapeutic program for physicians with potentially impairing health conditions such 440 as substance related disorders. Participating in the monitoring program, physicians 441 with substance related disorders are allowed to keep on working whereas a regularly 442 proof of abstinence has to be shown. Measuring EtG in urine, Skipper and colleagues 443 (Skipper et al., 2004) showed that of 100 randomly collected samples, no sample 444 was positive for alcohol using standard testing; however, seven were positive for EtG 
445 (0.5 - $196 \mathrm{mg} / \mathrm{L})$, suggesting recent alcohol use. EtG testing can provide additional 446 information and consequently, may lead to further treatment and improvement for the 447 patient (Skipper et al., 2004, 2013).

448 b) The usefulness of EtG measurement during inpatient treatment in a rehabilitation 449 program has been shown in two studies (Junghanns et al., 2009; Wetterling et al. 450 2014). The results suggest that there is a considerable number of inpatients 451 consuming alcohol during weekend leaves which is not detected by self-report or 452 breath alcohol analyses. Of patients who lapsed during weekend leaves, a high 453 proportion did not complete treatment. Furthermore, lapsers completing treatment did 454 have a significantly reduced chance to reach abstinence during follow-ups.

455 3) Pharmacotherapy efficacy studies:

456 As an objective outcome parameter, EtG testing has shown to be useful in 457 pharmaco-therapeutical studies (Dahl et al., 2011b; Mitchell et al., 2012, Jatlow et al., 458 2014).

459 4) Hangover state:

460 A potential role of EtG in the context of neurocognitive impairment following heavy 461 drinking, usually referred to as hangover state, has previously been suggested 462 (Wurst et al., 2003a; Stephens et al., 2014). Results of a recent study (Hoiseth et al., $4632015)$ seem to consolidate this idea.

464 5) In addition, EtG can also be detected in specimens of dried blood, which is of 465 relevance for forensic investigations (Kaufmann \& Alt, 2008; Winkler et al., 2011; 466 Hernandez Redondo et al., 2013)

467 6) Liver transplantation:

468 Alcohol-related liver disease accounts for up to $30 \%$ of liver transplants (Burroughs 469 et al., 2006). Post-operatively, $20-25 \%$ of the patients' lapse or relapse to alcohol 470 intake (Kelly et al., 2006; DiMartini et al., 2006). In 18 patients with ALD (alcohol liver 
471 disease) Erim et al. (2007) found no self-report on alcohol consumption. One out of 472127 tests for breath alcohol was positive, whereas 24 of 49 urine samples were 473 positive for EtG. Webzell et al. (2011), who found self-reported alcohol consumption 474 in $3 \%$ in contrast to $20 \%$ positive urine EtG and EtS tests, reported comparable 475 results. Recently, Piano et al. (2014) found that the combination of AUDIT-C and EtG 476 in urine improves the detection of alcohol consumption in liver transplant candidates 477 and liver transplant recipients and showed higher accuracy in detecting alcohol 478 consumption than the combination of AUDIT-C and CDT.

479 EtG in hair (HEtG) allows retrospective determination of alcohol consumption for up 480 to 6 months that is the abstention period often required by transplant programs prior 481 to listing patients. Several studies have evaluated HEtG concentrations in liver 482 transplant patients, proposing it to be a highly specific and useful tool for the 483 monitoring of alcohol use before, and after liver transplantation (Sterneck et al., 2013; 484 Hilke et al., 2014) and superior to traditional markers. Further substantial advantages 485 compared to routine methods of alcohol detection in urine or blood are, that obtaining 486 hair samples is non-invasive and storage of the samples is easy. Despite their 487 excellent profile, it is not advisable to use the results of hair testing for alcohol 488 markers in isolation and conclusions always should be corroborated by a clinical 489 assessment and interpretation.

490 On this background, Allen et al (2013) conclude in a recent review regarding liver 491 transplantation that ethyl glucuronide tests in urine and hair are complementary to 492 self-reports and questionnaires, yielding valuable information on alcohol 493 consumption, which is relevant in diagnosis and therapy.

494 7) Alcohol metabolites and fetal alcohol syndrome (FAS)

495 Alcohol consumption during pregnancy may lead to fetal alcohol syndrome (FAS) and 496 the fetal alcohol spectrum disorder (FASD), characterized by congenital 
497 abnormalities, cognitive dysfunction and developmental problems. Estimations report 498 that the prevalence of FAS and FASD is 0.2 to 1 per 100 life-births in industrialized 499 countries (Sampson et al., 1997; Stade et al., 2009).

500 A recent study reported that $50 \%$ of Italian and $40 \%$ of Spanish women occasionally 501 consumed alcohol during pregnancy (Vagnarelli et al., 2011).

502 Alcohol intake during pregnancy can be investigated in

503 a) maternal (including hair, blood, urine) and

504 b) fetal specimen (meconium) (Joya et al., 2012).

505 To date there is only one study (Wurst et al., 2008c) employing EtG in urine and hair 506 in pregnant women assessing alcohol intake compared with self-reports: Women at 507 the end of the second trimester were included. The AUDIT identified $25.2 \%$ women 508 consuming any alcohol during pregnancy. None of the participants scored above the 509 gender-specific AUDIT score higher than the cut-off value of 4 points. However, 510 according to the hair analysis, 12 women drank $20-40 \mathrm{~g}$ ethanol per day, and 4 had 511 an intake over $60 \mathrm{~g} /$ day (Wurst et al., 2008c). The results of the study also indicate 512 that the combination of AUDIT and biomarkers identified more alcohol use than the 513 questionnaire alone.

514 These results support the application of direct alcohol metabolites in pregnant women 515 since increases of \%CDT (percent of carbohydrate deficient transferrin vs. total 516 transferrin) and its isoforms were reported for this specific population (Bianchi et al., 517 2011; Kenan et al., 2011).

518 Studies on fetal specimen include current measures of meconium. These measures 519 are a cumulative indicator of alcohol consumption, since it is formed between the $12^{\text {th }}$ 520 and $16^{\text {th }}$ week of pregnancy. While the first studies investigated FAEEs 521 concentrations, recent research focused on EtG and EtS. The largest study 522 investigated meconium of 607 newborns. $7.9 \%$ of specimens indicated maternal 
523 alcohol intake during pregnancy. Low maternal education level and age were

524 associated with biomarker values above the cut-off (Pichini et al., 2012). In contrast, 525 Goecke et al., (2014) found in 557 births no correlation between socioeconomic or 526 psychological characteristics and those women positively tested for alcohol use via 527 meconium. Regarding FAEEs detection, the specimen has to be investigated 528 promptly. One study reported that negative meconium values in 19 babies turned 529 positive within 59 hours. Following the authors' in-vivo- and in-vitro studies, this 530 change may be caused by contamination through nutritional components, postnatal 531 feces and ethanol-producing germs (Zelner et al., 2012). This may also be the cause 532 for $82.8 \%$ EtG and $22.2 \%$ FAEEs positive values in meconium, reported by another 533 study (Morini et al., 2010b). Results of a recent study suggest that maternal ethanol 534 intake was better represented by meconium EtG $\geq 30 \mathrm{ng} / \mathrm{g}$ than by currently used 535 FAEE cutoffs (Himes et al., 2015).

536 Also the usefulness of PEth measurement in whole blood during pregnancy was 537 described (Stewart et al., 2010; Kwak et al., 2014). In addition, capillary blood 538 sampling for PEth analysis on DBS has been applied for neonatal screening of 539 prenatal alcohol exposure with promising results (Bakhireva et al., 2013, Bakhireva et $540 \quad$ al., 2014) 2014)

\section{Summary and Discussion:}

543 In summary, ethanol metabolites reflect the spectrum between short-term intake of

544 small amounts and long-term use of large amounts of alcohol. Cut-off values and 545 influencing factors are summarized in tables 1 and 2. Appropriate methods of 546 analysis and pre-analytics are crucial for a valid and reliable detection of alcohol 547 biomarkers. For EtG, the most frequently used marker, the most recommended 548 methods for detection are chromatographic approaches, which are considered as 
549 standard methods especially in forensic cases. A commercial test-kit is available and

550 contributed to wide distribution of the test. Laboratory values always require critical 551 clinical reappraisal, especially since EtG is detectable in urine using LC-MS/MS even

552 after an ingestion of low amounts of alcohol $(1 \mathrm{~g})$, which also occurs in some food, 553 drugs and disinfectants. Individuals with the motivation to or obligation for abstinence 554 have to be informed about these "hidden contents" to avoid unintentional intake of 555 alcohol. For forensic purposes, the current cut-off value of $0.1 \mathrm{mg} / \mathrm{L}$ should be 556 adapted to exclude cases of unintentional alcohol use. With respect to differences in 557 formation and degradation, EtG and EtS should be analyzed together, if possible. In 558 the absence of known influencing factors, EtG in hair can be recommended as a 559 marker for alcohol intake over the last 3 months. Furthermore, guidelines for 560 interpretations of values are available from the Society of Hair Testing (SOHT, 2014). 561 While positive urine values of EtG and EtS can be in accord with 562 innocent/unintentional alcohol intake, positive values of PEth are related to previous 563 intoxications of $0.05 \mathrm{~g} / \mathrm{dL}$ and more.

564 Therefore, PEth is currently used to differentiate between moderate drinking and 565 excessive alcohol use, based on thresholds derived from clinical investigations. A 566 suggested threshold of 0.3 micromole/Liter $(210 \mathrm{ng} / \mathrm{mL}$ ) PEth (Helander and 567 Hansson, 2013) seems promising, however needs further evaluation and verification 568 by studies with larger numbers of social drinkers. Furthermore, inter-individual 569 differences should be investigated, which might depend on differences in 570 phospholipase-D activities. New developments achieved by more sensitive analysis 571 methods and drinking experiments show the potential of PEth in abstinence 572 monitoring (Schrock et al., 2014). Due to stability issues the use of "dried blood 573 spots"(DBS) in PEth analysis is promising: a) In vitro formation of PEth in alcohol574 containing blood does not occur after drying blood on filter paper, b) it may facilitate 
575 blood sampling (capillary blood instead of venous blood), storage and shipping of 576 samples.

577 As biomarkers with high sensitivity and specificity covering complimentary time 578 windows from hours to several months, depending on the biological material used for 579 analysis and the choice of the respective biomarker, ethanol metabolites can be 580 applied in different settings such as screening, prevention, diagnosis and therapy of 581 alcohol use disorders and alcohol intake in general, among others.

582

583 
Aderjan R, Babel B, Briellmann T, Daldrup T. Demme U, Hallbach J, Hartung M,

Harzer K, Herbold M, von Meyer L, Moeller M, Musshoff F, Schmitt G, Weinmann W

(2000) Anlage zu den Richtlinien der GTFCh zur Qualitätssicherung bei forensisch-

toxikologischen Untersuchungen. Anhang A: Anforderung an einzelne

Analysenmethoden. Toxichem Krimtech; 67: 13-16

591

Agius R (2014) Utility of coloured hair for the detection of drugs and alcohol. Drug Test Anal 6 (S1): 110-9.

Albermann ME, Musshoff F, Aengenheister L, Madea B (2012a) Investigations on the influence of different grinding procedures on measured ethyl glucuronide concentrations in hair determined with an optimized and validated LC-MS/MS method. Anal Bioanal Chem 403 (3): 769-776.

601 Preliminary investigations on ethyl glucuronide and ethyl sulfate cutoffs for detecting

602 alcohol consumption on the basis of an ingestion experiment and on data from 603 withdrawal treatment. Int J Legal Med 126 (5): 757-764. transplant patients with alcoholic liver disease. Liver Transpl 9(4):369-376.

608 Alling C, Gustavsson L, Änggård E (1983) An abnormal phospholipid in rat organs 609 after ethanol. FEBS Lett 152: 24-28. 
611 Appenzeller BM, Schuman M, Yegles M, Wennig R (2007a) Ethyl glucuronide

612 concentration in hair is not influenced by pigmentation. Alcohol Alcohol 42: 326-327.

613

614 Appenzeller BMR, Agirman R, Neuberg P, Yegles M, Wennig R (2007b) Segmental 615 determination of ethyl glucuronide in hair: A pilot study. Forensic Sci Int 173: 87-92.

616

617 Aradottir S, Asanovska G, Gjerss S, Hansson P, Alling C (2006) Phosphatidylethanol

618 (PEth) concentrations in blood are correlated to reported alcohol intake in alcohol-

619 dependent patients. Alcohol Alcohol 41: 431-437.

620

621 Aradóttir S, Seidl S, Wurst FM et Jönsson BA, Alling C (2004) Phosphatidylethanol in

622 human organs and blood: a study on autopsy material and influences by storage

623 conditions. Alcohol Clin Exp Res 28 (11): 1718-1723.

624

625 Aradottir S \& Olsson BL (2005) Methodological modifications on quantification of 626 phosphatidylethanol in blood from humans abusing alcohol, using high-performance 627 liquid chromatography and evaporative light scattering detection. BMC Biochem 6: 62818.

629

630 Arndt T, Gierten B, Güssregen B, Werle A, Grüner J (2009) False-positive ethyl

631 glucuronide immunoassay screening associated with chloral hydrate medication as

632 confirmed by LC-MS/MS and self-medication.Forensic Sci Int 184:27-9.

633 Arndt T, Schröfel S, Stemmerich K (2013) Ethyl glucuronide identified in commercial 634 hair tonics. Forensic Sci Int 10;231(1-3):195-8. 
636 Arndt T, Schröfel S, Güssregen, B, Stemmerich K (2014a) Inhalation but not

637 transdermal resorption of hand sanitizer ethanol causes positive ethyl glucuronide 638 findings in urine. Forensic Sci In 237:126-130.

639

640 Arndt T, Beyreiß R, Schröfel S, Stemmerich K (2014b) Cross-reaction of propyl and 641 butyl alcohol glucuronides with an ethyl glucuronide enzyme immunoassay. Forensic 642 Sci Int 241:84-6.

643

644 Auwärter V, Kiessling B, Pragst F (2004) Squalene in hair- a natural reference 645 substance for the improved interpretation of fatty acid ethyl ester concentrations with 646 respect to alcohol misuse. Forensic Sci In 145: 149-159.

647

648 Auwärter V, Sporkert F, Hartwig S Pragst F, Vater H, Diefenbacher A (2001) Fatty 649 acid ethyl esters in hair as markers of alcohol consumption. Segmental hair analysis 650 of alcoholics, social drinkers, and teetotalers. Clin Chem 47: 2114-2123.

652 Babenko NA, Kharchenko VS (2012) Ceramides inhibit phospholipase D-dependent 653 insulin signaling in liver cells of old rats. Biochemistry (Mosc) 77(2):180-6.

655 Bakhireva LN, Leeman L, Savich RD, Cano S, Gutierrez H, Savage DD, Rayburn WF 656 (2014) The Validity of Phosphatidylethanol in Dried Blood Spots of Newborns for the 657 Identification of Prenatal Alcohol Exposure. Alcohol Clin Exp Res 38(4):1078-85. 658

659 Bakhireva LN, Savich RD, Raisch DW, Cano S, Annett RD, Leeman L, Garg M, Goff 660 C, Savage D (2013) The feasibility and cost of neonatal screening for prenatal 
661 alcohol exposure by measuring phosphatidylethanol in dried blood spots. Alcohol Clin 662 Exp Res, 37, 1008-15.

663

664 Baranowski S, Serr A, Thierauf A (2008) In vitro study of bacterial degradation of 665 ethyl glucuronide and ethyl sulfate. Int J Leg Med 122: 389- 393.

666

667 Berger L, Fendrich M, Jones J, Fuhrmann D, Plate C, Lewis D (2013) Ethyl

668 glucuronide in hair and fingernails as a long-term alcohol biomarker. Addiction $669 \quad 109: 425-431$.

670

671 Bianchi V, Ivaldi A, Raspagni A, Arfini C, Vidali M (2011) Pregnancy and variations of 672 carbohydrate-deficient transferrin levels measured by the candidate reference HPLC 673 method. Alcohol Alcohol 46 (2): 123-127.

674

675 Bora PS, Guruge DG, Miller DD, Chaitman BR, Ruyle MS (1996) Purification and 676 characterization of human heart fatty acid ethyl ester synthase/carboxylesterase. J 677 Mol Cell Cardiol 28: 2027-2032.

678

679 Bora PS, Spilburg CA, Lange LG (1989) Metabolism of ethanol and carcinogens by 680 glutathione transferases. Prot Natl Acad Sci USA 86:4470-4473.

682 Borucki K, Schreiner R, Dierkes J, Jachau K, Krause D, Westphal S, Wurst FM, Luley 683 C, Schmidt-Gayk H (2005) Detection of recent ethanol intake with new markers: 684 comparison of fatty acid ethyl esters in serum and of ethyl glucuronide and the ratio 685 of 5-hydroxytryptophol to 5-hydroxyindole acetic acid in urine. Alcohol Clin Exp Res 686 29: 781-787. 
688 Boscolo-Berto R, Facretto D, Cecchetto G, Vincenti M, Kronstrand R, Ferrara SD,

689 Viel G (2014) Sensitivity and specificity of EtG in hair as a marker of chronic

690 excessive drinking. Pooled analysis of raw data and meta-analysis of diagnostic

691 accuracy studies. Ther Drug Monit 36(5):560-75.

692

693 Boström H, Vestermark A (1960) Studies on ester sulfates. 7. On the excretion of 694 sulphate conjugates of primary aliphatic alcohols in the urine of rats. Acta Physiol 695 Scand 48: 88-94.

696

697 Böttcher M, Beck O, Helander A (2008) Evaluation of a new immunoassay for urinary 698 ethyl glucuronide testing. Alcohol Alcohol 43: 46-48.

699

700 Burroughs AK, Sabin CA, Rolles K, Delvart V, Karam V, Buckels J, O'Grady JG,

701 Castaing D, Klempnauer J, Jamieson N, Neuhaus P, Lerut J, de Ville de Goyet J,

702 Pollard S, Salizzoni M, Rogiers X, Muhlbacher F, Garcia Valdecasas JC, Broelsch C,

703 Jaeck D, Berenguer J, Gonzalez EM, Adam R; European Liver Transplant

704 Association (2006) 3-month and 12-month mortality after first liver transplant in adults

705 in Europe: predictive models for outcome. Lancet 367: 225-232.

706

707 Conigrave KM, Degenhardt LJ, Whitfield B, Saunders JB, Helander A, Tabakoff B 708 (2002) On behalf of the WHO/ISBRA study on biological state and trait markers of 709 alcohol use and dependence investigators. CDT, GGT, and AST as markers of 710 alcohol use: The WHO/ISBRA collaborative project. Alcohol Clin Exp Res 26: 332711339. 
713 Costantino A, Digregorio EJ, Korn W, Spayd S, Rieders F (2006) The effect of the

714 use of mouthwash on ethylglucuronide concentration in urine. J Anal Toxicol 30:

$715 \quad 659-662$.

716

717 Crunelle CL, Cappelle D, Covaci A, van Nuijs AL, Maudens KE, Sabbe B, Dom G, 718 Michielsen P, Yegles M, Neels H (2014a) Hair ethyl glucuronide as a biomarker of 719 alcohol consumption in alcohol-dependent patients: role of gender differences. Drug 720 Alcohol Depend 141:163-6.

722 Crunelle CL, Yegles M, van Nuijs AL, Covaci A, De Doncker M, Maudens KE, Sabbe, 723 B, Dom G, Lambert WE, Michielsen P, Neels H (2014b) Hair ethyl glucuronide levels 724 as amarker for alcohol use and abuse: a review of the current state of the art. Drug 725 Alcohol Depend 134:1-11.

726

727 Dahl H, Stephanson N, Beck O, Helander A (2002) Comparison of urinary excretion 728 characteristics of ethanol and ethyl glucuronide. J Anal Toxicol 26: 201-204.

730 Dahl H, Voltaire CarlssonA, Hillgren K, Helander A (2011a) Urinary ethyl glucuronide 731 and ethyl sulfate testing for detection of recent drinking in an outpatient treatment 732 program for alcohol and drug dependence. Alcohol Alcohol 46 (3): 278-282.

734 Dahl H, Hammarberg A, Franck J, Helander A (2011b) Urinary ethyl glucuronide and 735 ethyl sulfate testing for recent drinking in alcohol-dependent outpatients treated with 736 acamprosate or placebo. Alcohol Alcohol 46 (5): 553-557. 
738 DiMartini A, Day N, Dew MA Javed L, Fitzgerald MG, Jain A, Fung JJ, Fontes P 739 (2006) Alcohol consumption patterns and predictors of use following liver

740 transplantation for alcoholic liver disease. Liver Transpl 12: 813-820.

742 Dresen S, Weinmann W, Wurst FM (2004) Forensic confirmatory analysis of ethyl

743 sulfate - a new marker for alcohol consumption - by liquid chromatography

744 /electrospray ionisation/tandem mass spectrometry. J Americ Soc Mass Spectrom 745 15: 1644-1648.

746

747 Erim Y, Bottcher M, Dahmen U Beck O, Broelsch CE, Helander A (2007) Urinary 748 ethyl glucuronide testing detects alcohol consumption in alcoholic liver disease 749 patients awaiting liver transplantation. Liver Transpl 13: 757-761.

751 Ettlinger J, Kirchen L, Yegles M (2014) Influence of thermal hair straightening on 752 ethyl glucuronide content in hair. Drug Test Anal 6: 74-7.

754 Faller A, Richer B, Kluge M, Koenig P, Seitz HK, Skopp G (2013) Stability of phosphatidylethanol species in spiked and authentic whole blood and matching dried 756 blood spots. Int J Legal Med 127, 603-10.

758 Ferreira LM, Binz T, Yegles M (2012) The influence of ethanol containing cosmetics 759 on ethyl glucuronide concentration in hair. Forensic Sci Int 218: 123-125.

761 Foti RS, Fisher MB (2005) Assessment of UDP-glucuronosyltransferase catalyzed

762 formation of ethyl glucuronide in human liver microsomes and recombinant UGTs.

763 Forensic Sci Int 153 (2): 109-116. 
765 Fu J, Liu H, Xing H, Sun H, Ma Z, Wu B (2014) Comparative analysis of

766 glucuronidation of ethanol in treeshrews, rats and humans. Xenobiotica 44(12):1067$767 \quad 1073$

769 Gareri J, Appenzeller B, Walasek P, Koren G (2011) Impact of hair-care products on 770 FAEE hair concentrations in substance abuse monitoring. Anal Bioanal Chem $771 \quad 400(1): 183-8$.

772

773 Gitto S, Micco L, Conti F, Andreone P, Bernardi M (2009) Alcohol and viral hepatitis: 774 A mini-review. Dig Liver Dis 41: 67-70.

Gnann H, Weinmann W, Engelmann C, Wurst FM, Skopp G, Winkler M, Thierauf A, Auwärter V, Dresen S, Ferreirós Bouzas N (2009) Selective detection of phosphatidylethanol homologues in blood as biomarkers for alcohol misuse by LCESI-MS/MS. J Mass Spectrom 44 (9): 1293-1299.

780

781 Gnann H, Engelmann C, Skopp G, Winkler M, Auwärter V, Dresen S, Ferreirós N, 782 Wurst FM, Weinmann W (2010) Identification of 48 homologues of 783 phosphatidylethanol in blood by LC-ESI-MS/MS. Anal Bioanal Chem 396: 2415-23.

785 Gnann H (2011) Phosphatidylethanol - Ein Alkoholkonsummarker auf dem Weg in 786 die klinisch-forensische Routinediagnostik. Dissertation, University of Freiburg,

787 Germany. http://www.freidok.uni-

788 freiburg.de/volltexte/8428/pdf/Diss Heike Gnann.pdf. Accessed 15 April 2014: p. p. 789101 
791 Gnann H, Weinmann W, Thierauf A (2012) Formation of phosphatidylethanol and its 792 subsequent elimination during an extensive drinking experiment over 5 days. Alcohol 793 Clin Exp Res 36 (9): 1507-1511.

794

795 Gnann H, Thierauf A, Hagenbuch F, Röhr B, Weinmann W (2014) Time dependence 796 of elimination of different PEth homologues in alcoholics in comparison with social 797 drinkers. Alcohol Clin Exp Res 38:322-326.

798

799 Goecke TW, Burger P, Fasching PA, Bakdash A, Engel A, Häberle L, Voigt F, 800 Faschingbauer F, Raabe E, Maass N, Rothe M, Beckmann MW, Pragst F, Kornhuber $801 \mathrm{~J}(2014)$ Meconium indicators of maternal alcohol abuse during pregnancy and 802 association with patient characteristics. Biomed Res Int Epub 2014 Mar 30

803

804 González-Illán F, Ojeda-Torres G, Díaz-Vázquez LM, Rosario O (2011). Detection of 805 fatty acid ethyl esters in skin surface lipids as biomarkers of ethanol consumption in 806 alcoholics, social drinkers, light drinkers, and teetotallers using a methodology based 807 on microwave-assisted extraction followed by solid-phase microextraction and gas 808 chromatographymass spectrometry. J Anal Toxicol 2011; 35 (4): 232-237. 809

810 Gustavsson L, Alling C (1987) Formation of phosphatidylethanol in rat brain by 811 phospholipase D. Biochem Biophys Res Commun 142: 958- 963.

812

813 Hahn JA, Dobkin LM, Mayanja B, Emenyonu NI, Kigozi IM, Shiboski S, Bangsberg 814 DR, Gnann H, Weinmann W, Wurst FM (2012) Phosphatidylethanol (PEth) as a 
815 biomarker of alcohol consumption in HIV-Positive patients in sub-Saharan Africa.

816 Alcohol Clin Exp Res 36 (5): 854-862.

817

818 Halter CC, Laengin A, Al-Ahmad A, Wurst FM, Weinmann W, Kuemmerer K (2009)

819 Assessment of the stability of the ethanol metabolite ethyl sulfate in standardised

820 degradation tests. Forensic Sci Int 186 (1): 52-55.

821

822 Halter CC, Dresen S, Auwaerter V, Wurst FM, Weinmann W (2008) Kinetics in serum

823 and urinary excretion of ethyl sulfate and ethyl glucuronide after medium dose

824 ethanol intake. Int J Legal Med 122: 123-128.

825

826 Hannuksela ML, Liisanantti MK, Nissinen AE, Savolainen MJ (2007) Biochemical

827 markers of alcoholism. Clin Chem Lab Med 45: 953-961.

828

829 Hartmann S, Aradottir S, Graf M Wiesbeck G, Lesch O, Ramskogler K, Wolfersdorf

830 M, Alling C, Wurst FM (2007) Phosphatidylethanol as a sensitive and specific

831 biomarker - comparison with gamma glutamyl transpeptidase, mean corpuscular

832 volume and carbohydrate-deficient transferrin. Addict Biol 12: 81-84.

833

834 Hartwig S, Auwärter V, Pragst F (2003) Effect of hair care and hair cosmetics on the

835 concentrations of fatty acid ethyl esters in hair as markers of chronically elevated

836 alcohol consumption. Forensic Sci Int 131: 90-97.

837

838 Helander A, Beck O (2004) Mass Spectrometric Identification of Ethyl Sulfate as an

839 Ethanol Metabolite in Humans. Clin Chem 5: 936-937. 
841 Helander A, Dahl H (2005) Urinary tract infection: a risk factor for false-negative

842 urinary ethyl glucuronide but not ethyl sulfate in the detection of recent alcohol

843 consumption. Clin Chem 51 (9): 1728-1730.

844

845 Helander A, Hagelberg CA, Beck O, Petrini B (2009) Case report. Unreliable alcohol

846 testing in a shipping safety programme. Forensic Sci Int 189: e45-e47.

847

848 Helander A, Zheng Y (2009) Molecular species of the alcohol biomarker

849 phosphatidylethanol in human blood measured by LC-MS. Clin Chem 55 (7): 13958501405.

851

852 Helander A (2003) Biological markers in alcoholism. J Neural Transm 66: 15-32.

853

854 Helander A, Hansson T (2013) [National harmonization of the alcohol biomarker

855 PEth]. Lakartidningen 110: 1747-8.

856

857 Hernandez Redondo A, Körber C, König S, Längin A, Al-Ahmad A, Weinmann W 858 (2012) Inhibition of bacterial degradation of EtG by collection as dried urine spots 859 (DUS). Anal Bioanal Chem 402 (7): 2417-24.

860

861 Hernandez Redondo A, Schroeck A, Kneubuehl B, Weinmann W (2013)

862 Determination of ethyl glucuronide and ethyl sulfate from dried blood spots. Int J 863 Legal Med 127(4):769-75.

864

865 Hilke A, von Rothkirch Gregor, Eik V, Alexander M, Ansgar L, Dorothea F, Barbara S, 866 Bjoern N, Martina S (2014) Determination of ethyl glucuronide in hair for detection of 
867 alcohol consumption in patients after liver transplantation. Ther Drug Monit 2014 Dec

870 Himes SK, Dukes KA, Tripp T, Petersen J, Raffo C, Burd L, Odendaal H, Elliott AJ, 871 Hereld D, Signore C, Willinger M, Huestis MA (2015) for the Prenatal Alcohol in SIDS 872 and Stillbirth (PASS) Network. Clinical Sensitivity and Specificity of Meconium Fatty 873 Acid Ethyl Ester, Ethyl Glucuronide, and Ethyl Sulfate for Detecting Maternal Drinking 874 During Pregnancy. Clin Chem. 2015 Jan 16. [Epub ahead of print] 875

876 Høiseth G, Morini L, Ganss R, Nordal K, Mørland J (2013) Higher Levels of Hair Ethyl 877 Glucuronide in Patients with Decreased Kidney Function. Alcohol Clin Exp Res 37: 878 E14-6.

879

880 Høiseth G, Morini L, Polettini A, Christophersen A, Mørland J (2009) Blood kinetics of 881 ethyl glucuronide and ethyl sulphate in heavy drinkers during alcohol detoxification. 882 Forensic Sci Int 188: 52-6.

883

884 Hoiseth G, Nordal K, Pettersen E, Mørland J (2012) Prolonged urinary detection 885 times of EtG and EtS in patients with decreased renal function. Alcohol Clin Exp Res $88636(7): 1148-1151$.

887

888 Hoiseth G, Fosen JT, Liane V, Bogstrand St, Morland J (2015) Alcohol hangover as a 889 cause of Impairment in apprehended drivers. Traffic Inj Prev 16(4):323-8. 
891 Isaksson A, Walther L, Hansson T, Andersson A, Alling C (2011)

892 Phosphatidylethanol in blood (B-PEth): a marker for alcohol use and abuse. Drug 893 Test Anal 3: 195-200.

894

895 Jatlow PI, Agro A, Wu R, Nadim H, Toll BA, Ralevski E, Nogueira C, Shi J, Dziura JD, 896 Petrakis IL, O'Malleys SS (2014) Ethyl glucuronide and ethyl sulfate assays in clinical 897 trials, interpretation and limitations: results of a dose ranging alcohol challenge study 898 and 2 clinical trials. Alcohol Clin Exp Res 38: 2056-2065.

899

900 Junghanns K, Graf I, Pflüger J, Wetterling G, Ziems C, Ehrenthal D, Zöllner M, 901 Dibbelt L, Backhaus J, Weinmann W, Wurst FM (2009) Urinary ethyl glucuronide 902 (EtG) and ethyl sulphate (EtS) assessment: valuable tools to improve verification of 903 abstention in alcohol-dependent patients during in-patient treatment and at follow904 ups. Addiction 104: 921-926.

905

906 Joya X, Friguls B, Ortigosa S, Papaseit E, Martínez SE, Manich A, Garcia-Algar O, 907 Pacifici R, Vall O, Pichini S (2012) Determination of maternal-fetal biomarkers of 908 prenatal exposure to ethanol: A review. J Pharm Biomed Anal 69: 209-222. 909

910 Kaufmann E, Alt A (2008) Detection of ethyl glucuronide in dried human blood using 911 LC-MS/MS. Int J Legal Med 122: 245-249.

912

913 Kelly M, Chick J, Gribble R, Gleeson M, Holton M, Winstanley J, McCaughan GW, 914 Haber PS (2006) Predictors of relapse to harmful alcohol after orthotopic liver 915 transplantation. Alcohol Alcohol 41: 278-283. 
917 Kenan N, Larsson A, Axelsson O, Helander A (2011) Changes in transferrin

918 glycosylation during pregnancy may lead to false-positive carbohydrate-deficient

919 transferrin (CDT) results in testing for riskful alcohol consumption. Clin Chim Acta

$920 \quad 412(1):$ 129-133.

921

922 Kerekes I, Yegles M (2013) Coloring, bleaching, and perming: influence on EtG 923 content in hair. Ther Drug Monit 35: 527-9.

924

925 Kharbouche H, Steiner N, Morelato M, Staub C, Boutrel B, Mangin P, Sporkert F, 926 Augsburger M (2010) Influence of ethanol dose and pigmentation on the 927 incorporation of ethyl glucuronide into rat hair. Alcohol 44(6):507-14

928

929 Kobayashi M, Kanfer JN (1987) Phosphatidylethanol formation via

930 transphosphatidylation by rat brain synaptosomal phospholipase D. J Neurochem 48:

$931 \quad 1597-603$.

932

933 Kronstrand R, Brinkhagen L, Nyström FH (2012) Ethyl glucuronide in human hair 934 after daily consumption of 16 or $32 \mathrm{~g}$ of ethanol for 3 months. Forensic Sci Int 215(1): $935 \quad 51-55$.

936

937 Kulaga V, Velazquez-Armenta Y, Aleksa K, Vergee Z, Koren G (2009) The effect of 938 hair pigment on the incorporation of fatty acid ethyl esters (FSEE). Alcohol Alcohol 939 44: 287-292.

940

941 Kummer N, Wille SM, Di Fazio V, Ramírez Fernández MD, Yegles M, Lambert WE, 942 Samyn N (2015) Impact of the Grinding Process on the Quantification of Ethyl 
943 Glucuronide in Hair Using a Validated UPLC-ESI-MS-MS Method. J Anal Toxicol

$94439(1): 17-23$.

945

946 Kwak HS, Hand JY, Choi JS, Ahn HK, Ryu HM, Chung HJ, Cho DH, Shin CY,

947 Velazquez-Armenta EY, Nava-Ocampo AA (2014) Characterization of

948 phosphatidylethanol blood concentrations for screening alcohol consumption in early

949 pregnancy. Clin Toxicol (Phila) 52(1):25-31.

950

951 Laposata M (1999) Assessment of ethanol intake - current tests and new assays on

952 the horizon. Am J Clin Pathol 112: 443-450.

953

954 Liniger B, Nguyen A, Friedrich-Koch A, Yegles M (2010) Abstinence monitoring of 955 suspected drinking drivers: ethyl glucuronide in hair versus CDT. Traffic Inj Prev $95611(2): 123-6$.

957

958 Loftus N, Barnes A, Ashton S, Michopoulos F, Theodoridis G, Wilson I, Ji C,

959 Kaplowitz N (2011) Metabonomic investigation of liver profiles of nonpolar

960 metabolites obtained from alcohol-dosed rats and mice using high mass accuracy

961 MSn analysis. J Proteome Res 10 (2): 705-713.

962

963 Mann K (2002) Neue ärztliche Aufgaben bei Alkoholproblemen: von der

964 Behandlungskette zum Behandlungsnetz. Deutsches Ärzteblatt; 99 (10): 632-644.

965

966 Marques P, Tippets S, Allen JP, Javors M, Alling C, Yegles M, Pragst F, Wurst F

967 (2010) Estimating Driver Risk Using Alcohol Biomarkers, Interlock BAC Tests and

968 Psychometric Assessments. Addiction 105 (2): 226-239. 
970 Marques P, Hansson T, Isaksson A, Walther L, Jones J, Lewis D, Jones M (2011)

971 Detection of phosphatidylethanol (PEth) in the blood of drivers in an alcohol ignition 972 interlock program. Traffic Inj Prev 12(2):136-41.

973

974 Marques PR, Tippetts AS, Yegles M (2014) Ethylglucuronide in hair is a top predictor 975 of impaired driving recidivism, alcohol dependence, and a key marker of the highest 976 BAC interlock tests. Traffic Inj Prev 15(4):361-9.

977

978 Mitchell JM, Teague CH, Kayser AS, Bartlett SE, Fields HL (2012) Varenicline 979 decreases alcohol consumption in heavy-drinking smokers. Psychopharmacology $980223(3):$ 299-306.

981

Mönch B, Becker R, Nehls I (2013) Quantification of ethyl glucuronide in hair:effect of 983 milling on extraction efficiency. Alcohol Alcohol 48(5):558-63.

Moore RD, Bone LR, Geller G, Mamon JA, Stokes EJ, Levine DM (1989) Prevalence, 986 detection, and treatment of alcoholism in hospitalized patients. JAMA 261: 403-407.

Morini L, Zucchella A, Polettini A, Politi L, Groppi A (2010a) Effect of bleaching on 989 ethyl glucuronide in hair: an in vitro experiment. Forensic Sci Int 198:23-7.

991 Morini L, Groppi A, Marchei E, Vagnarelli F, Garcia Algar O, Zuccaro P, Pichini S 992 (2010b) Population Baseline of Meconium Ethyl Glucuronide and Ethyl Sulfate 993 Concentrations in Newborns of Nondrinking Women in 2 Mediterranean Cohorts. 994 Ther Drug Monit 2010, [Epub ahead of print] 
996 Nalesso A, Viel G, Cecchetto G, Mioni D, Pessa G, Favretto D, Ferrara SD (2011)

997 Quantitative profiling of phosphatidylethanol molecular species in human blood by 998 liquid chromatography high resolution mass spectrometry. J Chromatogr A 1218 (46): 999 8423-31.

1001 Niemelä O (2007) Biomarkers in alcoholism. Clin Chim Acta 377: 39-49.

1002

1003 Nissinen AE, Laitinen LM, Kakko S, Helander A, Savolainen MJ, Hörkkö S(2012) Low 1004 plasma antibodies specific for phosphatidylethanol in alcohol abusers and patients 1005 with alcoholic pancreatitis. Addict Biol; 17 (6): 1057-1067.

1006

1007 Piano S, Marchioro L, Gola E, Rosi S, Morando F, Cavallin M, Sticca A, Fasolato S,

1008 Forza G, Frigo AC, Plebani M, Zanus G, Cillo U, Gatta A, Angeli P (2014)

1009 Assessment of alcohol consumption in liver transplant candidates and recipients: the 1010 best combination of tools available. Liver Transplant 20: 815-822.

1011

1012 Pichini S, Marchei E, Vagnarelli F, Tarani L, Raimondi F, Maffucci R, Sacher B, 1013 Bisceglia M, Rapisardi G, Elicio MR, Biban P, Zuccaro P, Pacifici R, Pierantozzi A, 1014 Morini L (2012) Assessment of prenatal exposure to ethanol by meconium analysis: 1015 results of an Italian multicenter study. Alcohol Clin Exp Res 36 (3): 417-424. 1016

1017 Politi L, Morini L, Leone F, Polettini A (2006) Ethyl glucuronide in hair: is it a reliable 1018 marker of chronic high levels of alcohol consumption? Addiction 101(10):1408-12. 1019 
1020 Pragst F, Auwaerter V, Sporkert F, Spiegel K (2001) Analysis of fatty acid ethyl esters

1021 in hair as possible markers of chronically elevated alcohol consump-tion by

1022 headspace solid-phase microextraction (HS-SPME) and gas chromatography-mass

1023 spectrometry (GC-MS). Forensic Sci Int 121: 76-88.

1024

1025 Pragst F, Balikova MW (2006) State of the art in hair analysis for detection of drug 1026 and alcohol abuse. Clin Chim Acta 370: 17-49.

1027

1028 Pragst F, Yegles M (2008) Determination of fatty acid ethyl esters (FAEE) and ethyl 1029 flucuronide (EtG) in hair: a promising way for retrospective detection of alcohol abuse 1030 during pregnancy? Ther Drug Monit 30: 255-263.

1031

1032 Pragst F, Yegles M (2007) Alcohol markers in hair, in Analytical and pratical aspects

1033 drug testing in hair Boca Raton (Kintz P ed), pp 287-324. CRC Press Taylor \&

1034 Francis, London, New York.

1035

1036 Rehm J, Mathers C, Popova S, Thavorncharoensap M, Teerawattananon Y, Patra J

1037 (2009) Global burden of disease and injury and economic cost attributable to alcohol

1038 use and alcohol use disorders. The Lancet 373: 2223-33.

1039

1040 Rohrig TP, Huber C, Goodson L, Ross W (2006) Detection of ethylglucuronide in 1041 urine following the application of Germ-X. J Anal Toxicol 30(9): 703-704.

1042

1043 Rubinsky AD, Sun H, Blough DK, Maynard C, Bryson CL, Harris AH, Hawkins EJ,

1044 Beste LA, Henderson WG, Hawn MT, Hughes G, Bishop MJ, Etzioni R, Tønnesen H, 
1045 Kivlahan DR, Bradley KA (2012) AUDIT-C alcohol use screening results and

1046 postoperative inpatient health care use. J Am Coll Surg 214 (3): 296-305.

1047

1048 Safdar K, Schiff ER (2004) Alcohol and hepatitis C. Semin Liver Dis 24 (3): 305-315.

1049

1050 SAMHSA. The Role of Biomarkers in the Treatment of Alcohol Use Disorders.

10512012 Revision. Available at: http://store.samhsa.gov/shin/content/SMA12-

1052 4686/SMA12-4686.pdf. Accessed January 22, 2015.

1053

1054 Sampson PD, Streissguth AP, Bookstein FL, Little RE, Clarren SK, Dehaene P,

1055 Hanson JW, Graham JM Jr (1997) Incidence of fetal alcohol syndrome and

1056 prevalence of alcohol-related neurodevelopmental disorder. Teratology 56 (5): 317-

1057326.

1058

1059 Saunders JB, Aasland OG, Babor TF de la Fuente JR, Grant M (1993) Development

1060 of the Alcohol Use Disorders Identification Test (AUDIT): WHO Collaborative Project

1061 on Early Detection of Persons with Harmful Alcohol Consumption - II. Addiction 88:

$1062791-804$.

1063

1064 Schlögel H, Dresen S, Spaczynski K, Stoertzel M, Wurst FM, Weinmann W (2005)

1065 Stability of ethyl glucuronide in urine, post-mortem tissue and blood samples. Int $\mathrm{J}$

1066 Legal Med 30: 1-6.

1067

1068 Schmitt G, Aderjan R, Keller T, Wu M (1995) Ethyl-Glucuronide: An unusual ethanol

1069 metabolite in humans. Synthesis, analytical data, and determination in serum and

1070 urine. J Anal Toxicol 19: 91-94. 
1072 Schneider H, Glatt H (2004) Sulfo conjugation of ethanol in humans in vivo and by

1073 individual sulfotransferase forms in vitro. Biochem J 383: 543 -9.

1074

1075 Schräder J, Rothe M, Pragst F (2012) Ethyl glucuronide concentrations in beard hair 1076 after a single alcohol dose: evidence for incorporation in hair root. Int J LegalMed 1077 126(5):791-9.

1078

1079 Schröck A, Thierauf A, Weinmann W. Phosphatidylethanol - Pilot Study: Detection 1080 after Single Alcohol Consumption. 2014. Available at:

1081 http://www.irm.unibe.ch/unibe/medizin/irm/content/e7670/e491786/Phosphatidylethan 1082 ol-Pilot-Study_ger.pdf. Accessed May 15, 2014.

1083

1084 Schrock A, Thierauf A, Wurst FM, Thon N, Weinmann W (2014) Progress in 1085 monitoring alcohol consumption and alcohol abuse by phosphatidylethanol.

1086 Bioanalysis 6: 2285-94.

1087

1088 Schwab N, Skopp G (2014) Identification and preliminary characterization of UDP1089 glucuronosyltransferase catalyzing formation of ethyl glucuronide. Anal Bioanal 1090 Chem 406(9-10):2325-32.

1093 Skipper GE, Weinmann W, Thierauf A, Schäfer P, Wiesbeck G, Allen J, Miller M, 1094 Wurst FM (2004) Ethyl glucuronidea: a biomarker to identify alcohol use by health 1095 professionals recovering from substance use disorders. Alcohol Alcohol 39(5):445-9. 
1098 Skipper GE, Thon N, Dupont RL, Baxter L, Wurst FM (2013) Phosphatidylethanol:

1099 the potential role in further evaluating low positive urinary ethyl glucuronide and ethyl

1100 sulfate results. Alcohol Clin Exp Res 37(9):1582-6.

1101

1102 Society of Hair Testing. Consensus about alcohol markers in hair. 2014. Available at:

1103 http://www.soht.org/images/pdf/2014 Alcohol markers revision 13JUN14FINAL.pdf.,

1104 accessed January 30, 2015.

1105

1106 Society of Forensic Toxicologists and American Academy of Forensic Sciences,

1107 SOFT/AAFS. Forensic Toxicology Laboratory Guidelines. 2006. Available at:

1108 http://www.soft-tox.org/files/Guidelines 2006 Final.pdf. Accessed February 04, 2015

1109

1110 Spies C, Tonnesen H, Andreasson S, Helander A, Conigrave K (2001) Perioperative

1111 morbidity and mortality in chronic alcoholic patients. Alcohol Clin Exp Res 25 (5):

$1112 \quad 164-170$.

1113

1114 Sporkert F, Kharbouche H, Augsburger MP, Klemm C, Baumgartner MR (2012)

1115 Positive EtG findings in hair as a result of a cosmetic treatment. Forensic Sci Int 218

1116 (1): 97-100.

1117

1118 Stade B, Ali A, Bennett D, Campbell D, Johnston M, Lens C, Tran S, Koren G (2009)

1119 The burden of prenatal exposure to alcohol: revised measurement of cost. Can J Clin

1120 Pharmacol $16(1)$ : e91-e102.

1121 
1122 Stephens R, Grange JA, Jones K, Owen L (2014) A critical analysis of alcohol

1123 hangover research methodolgy for surveys or studies of effects on cognition.

1124 Psychopharmacology 231:2223-36.

1125

1126 Sterneck M, Yegles M, von Rothkirch G, Staufer K, Vettorazzi E, Schulz KH,Tobias

1127 N, Graeser C, Fischer L, Nashan B, Andresen-Streichert H (2013) Determination of

1128 ethyl glucuronide in hair improves evaluation of long-term alcohol abstention in liver 1129 transplant candidates. Liver Int. 2013 Jun 16 [Epub ahead of print]

1130

1131 Stewart SH, Koch DG, Burgess DM, Willner IR, Reuben A (2013) Sensitivity and

1132 Specificity of Urinary Ethyl Glucuronide and Ethyl Sulfate in Liver Disease Patients.

1133 Alcohol Clin Exp Res 37(1):150-5.

1134

1135 Stewart SH, Koch DG, Willner IR, Anton RF, Reuben A (2014) Validation of blood

1136 Phosphatidylethanol as an alcohol consumption biomarker in patients with chornic

1137 liver disease. Alcohol Clin Exp Res 38:1706-1711.

1138

1139 Stewart SH, Law TL, Randall PK, Newman R (2010) Phosphatidylethanol and alcohol

1140 consumption in reproductive age women. Alcohol Clin Exp Res 34 (3): 488-492.

1141

1142 Stewart SH, Reuben A, Brzezinski WA, Koch DG, Basile J, Randall PK, Miller PM

1143 (2009) Preliminary evaluation of phosphatidylethanol and alcohol consumption in

1144 patients with liver disease and hypertension. Alcohol Alcohol 44 (5): 464-467.

1145

1146 Suesse S, Pragst F, Mieczkowski T, Selavka CM, Elian A, Sachs H, Hastedt M,

1147 Rothe M, Campbell J (2012) Practical experiences in application of hair fatty acid 
1148 ethyl esters and ethyl glucuronide for detection of chronic alcohol abuse in forensic

1149 cases. Forensic Sci Int 218: 82-91.

1150

1151 Thierauf A, Halter CC, Rana S, Auwaerter V, Wohlfarth A, Wurst FM, Weinmann W

1152 (2009) Urine tested positive for ethyl glucuronide after trace amounts of ethanol.

1153 Addiction104 (12): 2007-2012.

1154

1155 Thierauf A, Wohlfarth A, Auwärter V, Perdekamp MG, Wurst FM, Weinmann W

1156 (2010) Urine tested positive for ethyl glucuronide and ethyl sulfate after the

1157 consumption of yeast and sugar. Forensic Sci Int 202: 1-3.

1158

1159 Thon N, Weinmann W, Yegles M, Preuss U, Wurst FM (2013) Direct Metabolites of

1160 Ethanol as Biological Markers of Alcohol Use: Basic Aspects and Applications.

1161 Fortschr Neurol Psychiatr 81(9):493-502.

1162

1163 Tonnesen H, Kehlet $\mathrm{H}$ (1999) Preoperative alcoholism and postoperative morbidity. $\mathrm{Br}$

1164 J Surg 86 (7): 869-874.

1165

1166 Tsujita T, Okuda H (1992) Fatty acid ethyl ester synthase in rat adipose tissue and its

1167 relationship to carboxylesterase. J Biol Chem 267: 23489-94

1168

1169 Vagnarelli F, Palmi I, García-Algar O, Falcon M, Memo L, Tarani L, Spoletini R,

1170 Pacifici R, Mortali C, Pierantozzi A, Pichini S (2011) A survey of Italian and Spanish

1171 neonatologists and paediatricians regarding awareness of the diagnosis of FAS and

1172 FASD and maternal ethanol use during pregnancy. BMC Pediatr 11:51. 
1174 Varga A, Alling C (2002) Formation of phosphatidylethanol in vitro in red blood cells

1175 from healthy volunteers and chronic alcoholics. J Lab Clin Med 140 (2): 79-83.

1176

1177 Varga A, Hansson P, Lundqvist C, Alling C (1998) Phosphatidylethanol in blood as a

1178 marker of ethanol consumption in healthy volunteers: comparison with other markers.

1179 Alcohol Clin Exp Res 22: 1832-37.

1180

1181 Viel G, Boscolo-Berto R, Cecchetto G, Fais P, Nalesso A, Ferrara SD.

1182 Phosphatidylethanol in blood as a marker of chronic alcohol use: a systematic review

1183 and meta-analysis. Int. J. Mol. Sci. 13(11), 14788-14812 (2012).

1184

1185 Walsham NE, Sherwood RA (2012) Ethyl glucuronide. Ann Clin Biochem 49:110-17.

1186

1187 Webzell I, Ball D, Bell J, Sherwood RA, Marsh A, O'Grady JG, Heaton ND (2011)

1188 Substance use by liver transplant candidates:an anonymous urinalysis study. Liver

1189 Transpl 17 (10): 1200-04.

1190

1191 Weinmann W, Schäfer P, Thierauf A, Schreiber A, Wurst FM (2004) Confirmatory

1192 analysis for ethyl glucuronide in urine by liquid chromatography/electrospray tandem

1193 mass spectrometry applying forensic guidelines. J Am Soc Mass Spectrom 15: 1881194193.

1195

1196 Wetterling T, Dibbelt L, Wetterling G, Göder R, Wurst F, Margraf M, Junghanns K

1197 (2014) Ethyl glucuronide (EtG): better than breathalyser or self-reports to detect

1198 covert short-term relapses into drinking. Alcohol Alcohol 49(1):51-4. 
1200 Wiens F, Zitztmann A, Lachance MA, Yegles M, Pragst F, Wurst FM, von Holst D,

1201 Guan SL, Spanagel R (2008) Chronic intake of fermented floral nectar by wild

1202 treeshrews. PNAS 105: 10426-31.

1203

1204 Winkler M, Kaufmann E, Thoma D, Thierauf A, Weinmann W, Skopp G, Alt A (2011)

1205 Detection of ethyl glucuronide in blood spotted on different surfaces. Forensic Sci Int 1206 210: 243-246.

1207

1208

Winkler M, Skopp G, Alt A et al. Comparison of direct and indirect alcohol markers

1209

with PEth in blood and urine in alcohol dependent inpatients during detoxication. Int.

1210 J. Legal Med. 127(4), 761-768 (2013).

1211

1212 World Health Organisation (WHO). Global Status Report on Alcohol and Health 2014.

1213 Available at:

1214 http://www.who.int/substance abuse/publications/global alcohol report/en/,

1215 Accessed, February 5, 2015

1216

1217 Wurst FM, Thon N,Weinmann W, Tippetts S, Marques P, Hahn JA, Alling C, Aradottir

1218 S, Hartmann S, Lakshman R (2012) Characterization of sialic acid index of plasma

1219 apolipoprotein $\mathrm{J}$ and phosphatidylethanol during alcohol detoxification - a pilot study.

1220 Alcohol Clin Exp Res 36 (2):251-257.

1221

1222 Wurst FM, Thon N, Yegles M, Halter C, Weinmann W, Laskowska B, Strasser J,

1223 Skipper G, Wiesbeck GA, Dürsteler-Macfarland K (2011) Optimizing heroin-assisted

1224 treatment (HAT): assessment of the contribution of direct ethanol metabolites in

1225 identifying hazardous and harmful alcohol use. Drug Alcohol Depend 115 (1): 57-61. 
1227 Wurst FM, Thon N, Aradottir S, Hartmann S, Wiesbeck GA, Lesch O, Skala K, 1228 Wolfersdorf M, Weinmann W, Alling C (2010) Phosphatidylethanol: normalization 1229 during detoxification, gender aspects and correlation with other biomarkers and self1230 reports. Addict Biol 15 (1): 88-95.

1232 Wurst FM, Haber PS, Wiesbeck G, Watson B, Wallace C, Whitfield JB, Halter C, 1233 Weinmann W, Conigrave KM (2008a) Assessment of alcohol consumption among 1234 hepatitis $\mathrm{C}$ positive people receiving opioid maintenance treatment using direct 1235 ethanol metabolites and self report - a pilot study. Addict Biol 13: 416-422 1236

1237 Wurst FM, Dürsteler-MacFarland KM, Auwaerter V, Ergovic S, Thon N, Yegles M, 1238 Halter C, Weinmann W, Wiesbeck GA (2008b) Assessment of alcohol use among 1239 methadone maintenance patients by direct ethanol metabolites and self-reports.

1240 Alcohol Clin Exp Res 32: 1552- 57.

1242 Wurst FM, Kelso E, Weinmann W, Pragst F, Yegles M, Sundström Poromaa I 1243 (2008c) Measurement of Direct Ethanol Metabolites suggests Higher Rate of Alcohol 1244 Use among Pregnant Women than found with the AUDIT - a Pilot Study in a

1245 Population-Based Sample of Swedish Women. Am J Obstet Gynecol 198 (4): 1246 407.e1-5.

1248 Wurst FM, Yegles M, Alling C, Aradottir S, Dierkes J, Wiesbeck GA, Halter CC, 1249 Pragst F, Auwaerter V (2008d) Measurement of direct ethanol metabolites in a case 1250 of a former driving under influence (DUI) of alcohol offender, now claming 1251 abstinence. Int J Legal Med 122: 235-239. 
1253 Wurst FM, Dresen S, Allen JP, Wiesbeck G, Graf M, Weinmann W (2006) Ethyl

1254 Sulphate: A Direct Ethanol Metabolite Reflecting Recent Alcohol Consumption.

1255 Addiction 101: 204-211.

1256

1257 Wurst FM, Wiesbeck GA, Metzger JW, Weinmann W (2004a) on behalf of the

1258 WHO/ISBRA study on biological state and trait markers of alcohol use and

1259 dependence. On sensitivity, specificity and the influence of various parameters on

1260 ethyl glucuronide levels in urine - Results from the WHO/ISBRA Study. Alcohol Clin

1261 Exp Res28: 1220-28.

1262

1263 Wurst FM, Alexson S, Wolfersdorf M, Bechtel G, Forster S, Alling C, Aradóttir S, 1264 Jachau K, Huber P, Allen JP, Auwärter V, Pragst F (2004b). Concentration of fatty 1265 acid ethyl esters in hair of alcoholics: Comparison to other biological state markers 1266 and self reported ethanol intake. Alcohol Alcohol 39: 33-38.

1267

1268 Wurst FM, Skipper GE, Weinmann W (2003a) Ethyl glucuronide--the direct ethanol

1269 metabolite on the threshold from science to routine use. Addiction 98: 51-61.

1270

1271 Wurst FM, Vogel R, Jachau K, Varga A, Alling C, Alt A, Skipper GE (2003b) Ethyl

1272 glucuronide detects recent alcohol use in forensic psychiatric inpatients. Alcohol Clin

1273 Exp Res 2003; 27: 471-476

1274

1275 Wurst FM, Kempter C Seid S, Alt A (1999a) et al. Ethyl glucuronide - amarker of

1276 alcohol consumption and a relapse marker with clinical and forensic implications.

1277 Alcohol Alcohol; 34: 71-77 
1279 Wurst FM, Kempter Ch, Seidl S, Gilg T, Jachau K, Alt A (1999b). Can ethyl 1280 glucuronide be determined in post mortem body fluids and tissues? Alcohol Alcohol $1281 \quad 34: 262-263$.

1284 Yegles M, Labarthe A, Auwärter V, Hartwig S, Vater H, Wennig R, Pragst F (2004) 1285 Comparison of ethyl glucuronide and fatty acid ethyl ester concentrations in hair of 1286 alcoholics, social drinkers and teetotallers. Forensic Sci Int 145: 167-173.

1288 Zheng Y, Beck O, Helander A (2011) Method development for routine liquid 1289 chromatography-mass spectrometry measurement of the alcohol biomarker 1290 phosphatidylethanol (PEth) in blood. Clin Chim Acta; 412: 1428-1435 1291

1292 Zelner I, Hutson JR, Kapur BM, Feig DS, Koren G (2012) False-Positive Meconium 1293 Test Results for Fatty Acid Ethyl Esters Secondary to Delayed Sample Collection. 1294 Alcohol Clin Exp Res 36 (9): 1497-1506. 
Table 1: Suggested cut-off values for different ethanol metabolites

\begin{tabular}{|c|c|c|c|}
\hline Biomarkers & $\begin{array}{l}\text { Amount of alcohol } \\
\text { consumption }\end{array}$ & Cut-off & Reference \\
\hline \multirow[t]{3}{*}{ EtG in hair } & $\begin{array}{l}\text { Abstinence and low intake } \\
(<10 \mathrm{~g} / \mathrm{d})\end{array}$ & $<7 \mathrm{pg} / \mathrm{mg}$ & \multirow[t]{3}{*}{ SOHT , 2014} \\
\hline & $\begin{array}{l}\text { Social consumption (20 - } 40 \\
\mathrm{~g} / \mathrm{d})\end{array}$ & $7-30 \mathrm{pg} / \mathrm{mg}$ & \\
\hline & $\begin{array}{l}\text { Excessive drinking } \quad(>60 \\
\mathrm{g} / \mathrm{d})\end{array}$ & $>30 \mathrm{pg} / \mathrm{mg}$ & \\
\hline \multirow{2}{*}{$\begin{array}{l}\text { FAEEs in } \\
\text { hair }\end{array}$} & Repeated alcohol intake & $\geq 200 \mathrm{pg} / \mathrm{mg}$ & \multirow[t]{2}{*}{ SOHT, 2014} \\
\hline & Excessive intake & $\geq 500 \mathrm{pg} / \mathrm{mg}$ & \\
\hline \multirow[t]{3}{*}{ EtG in urine } & Total abstinence & $0.1 \mathrm{mg} / \mathrm{L}$ & \multirow{3}{*}{$\begin{array}{l}\text { Thierauf et al., } \\
2009 \text {; } \\
\text { SAMHSA, } 2012\end{array}$} \\
\hline & $\begin{array}{l}\text { - unintentional intake } \\
\text { - recent alcohol use } \\
\text { - previous heavy alcohol } \\
\text { intake }\end{array}$ & $0.1 \mathrm{mg} / \mathrm{L}-0.5 \mathrm{mg} / \mathrm{L}$ & \\
\hline & $\begin{array}{l}\text { unintentional intake } \\
\text { unlikely, but possible, active } \\
\text { alcohol intake probable }\end{array}$ & $0.5-1 \mathrm{mg} / \mathrm{L}$ & \\
\hline EtS in urine & Total abstinence & $0.05 \mathrm{mg} / \mathrm{L}$ & $\begin{array}{l}\text { Albermann et } \\
\text { al., 2012b }\end{array}$ \\
\hline \multirow[t]{2}{*}{ PEth in blood } & Abstinence and low intake & $\begin{array}{l}150 \mathrm{ng} / \mathrm{mL}(0.22 \mu \mathrm{mol} / \mathrm{L}) \\
\text { total PEth with } \mathrm{HPLC} \\
20 \mathrm{ng} / \mathrm{mL}(0.03 \mu \mathrm{mol} / \mathrm{L}) \\
\text { PEth 16:0/18:1 (LC-MS/MS) } \\
35 \mathrm{ng} / \mathrm{mL} \quad(0.05 \quad \mu \mathrm{mol} / \mathrm{L}) \\
\text { PEth 16:0/18:1 (LC-MS/MS) }\end{array}$ & $\begin{array}{l}\text { Varga et al., } \\
\text { 1998; Aradottir } \\
\text { et al., } 2004 \\
\text { Gnann et al., } \\
2009 \text {; Schröck } \\
\text { et al., } 2014 \\
\text { Helander et al., } \\
2013\end{array}$ \\
\hline & $\begin{array}{l}\text { Drinking experiments: } \\
\text { a) Single consumption } \\
\text { (once, }>40 \mathrm{~g})\end{array}$ & $\begin{array}{l}120 \mathrm{ng} / \mathrm{mL}(0.17 \mu \mathrm{mol} / \mathrm{L}) \\
\text { PEth 16:0/18:1 (LC-MS/MS) }\end{array}$ & $\begin{array}{l}\text { Schröck et al., } \\
2014\end{array}$ \\
\hline
\end{tabular}




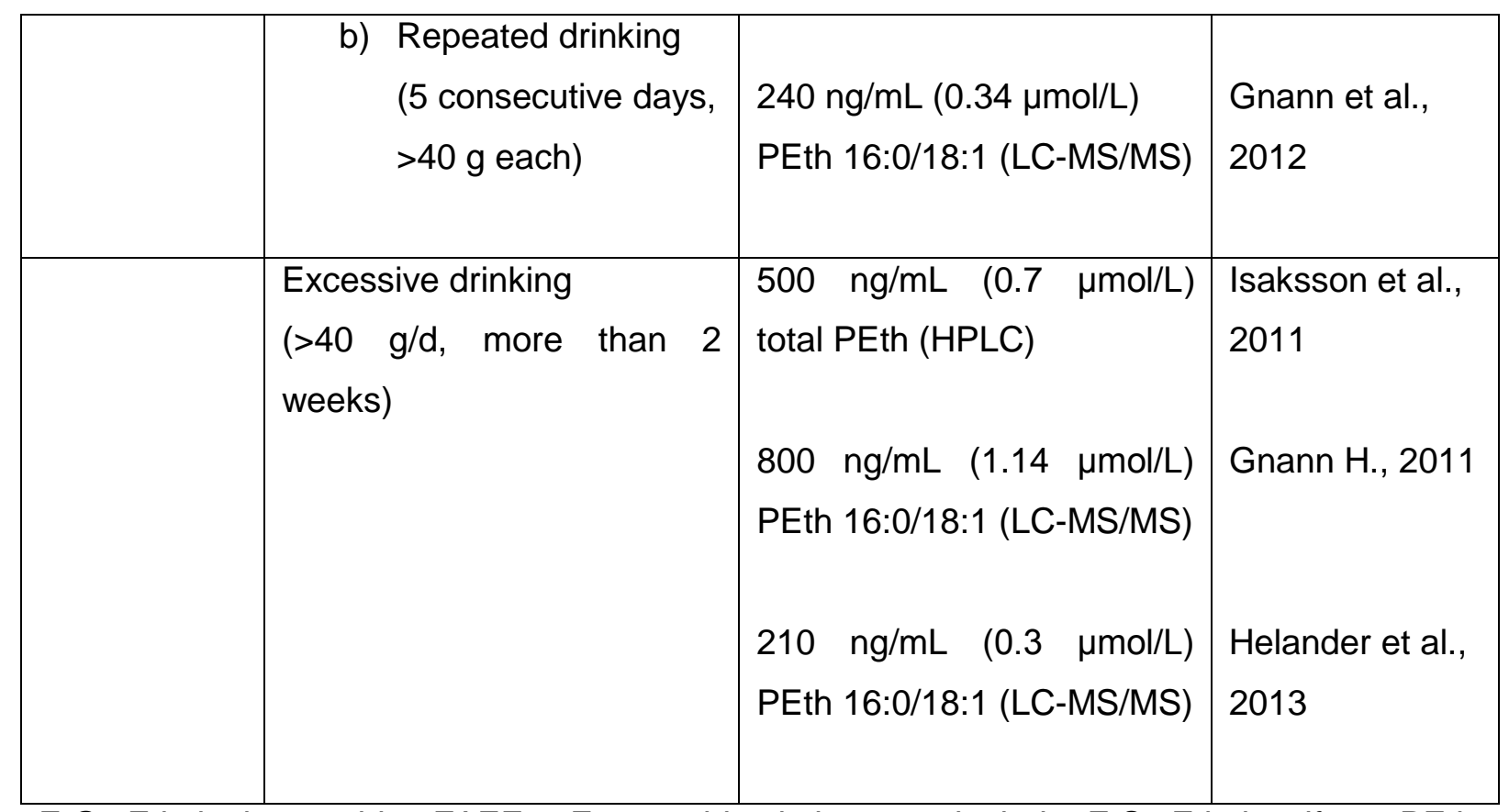

EtG: Ethyl glucuronide, FAEEs: Fatty acid ethyl esters in hair, EtS: Ethyl sulfate, PEth: Phosphatidylethanol; (modified according to Thon et al., 2013) LC-MS/MS: liquid chromatography - tandem mass spectrometry 
Table 2a: Factors without known influence on ethanol metabolite levels

\begin{tabular}{|c|c|c|}
\hline $\begin{array}{l}\text { Direct bio- } \\
\text { markers }\end{array}$ & Potential influencing factor & Reference \\
\hline \multirow[t]{2}{*}{ EtG in urine } & $\begin{array}{l}\text { No influence of E. coli on EtG levels in } \\
\text { urine, when dried urine spots are used }\end{array}$ & $\begin{array}{l}\text { Hernandez Redondo et } \\
\text { al., } 2012\end{array}$ \\
\hline & $\begin{array}{l}\text { Grade of liver disease, smoking, BMl, } \\
\text { body water content }\end{array}$ & Wurst et al., 2004a; \\
\hline EtS in urine & $\begin{array}{l}\text { No influence of E. coli on EtS levels in } \\
\text { urine, when dried urine spots are used }\end{array}$ & $\begin{array}{l}\text { Hernandez Redondo et } \\
\text { al., } 2012\end{array}$ \\
\hline \multirow[t]{4}{*}{ PEth } & Liver disease & \multirow[t]{2}{*}{ Stewart et al., 2009} \\
\hline & Hypertension & \\
\hline & $\begin{array}{l}\text { Storage of ethanol blood samples } \\
\text { Refrigerator temperature, }-80^{\circ} \mathrm{C}\end{array}$ & Aradottir et al., 2004 \\
\hline & Gender & Wurst et al., 2010 \\
\hline EtG in hair & $\begin{array}{l}\text { Hairsprays with ethanol, hair colour, } \\
\text { melanin content, age, gender, BMI }\end{array}$ & $\begin{array}{l}\text { Ferreira et al., 2012; } \\
\text { Kharbouche et al., } \\
\text { 2010; Kulaga et al., } \\
\text { 2009; Appenzeller et } \\
\text { al., } 2007 \\
\text { Crunelle et al., } 2014\end{array}$ \\
\hline
\end{tabular}

EtG: Ethyl glucuronide, FAEE: Fatty acid ethyl esters, EtS: Ethyl sulfate, PEth: Phosphatidylethanol, BMI: body mass index, RT: room ambient temperature, E. coli: Escherichia coli, C. sordelli: Clostridium sordelli (modified according to Thon et al., 2013) 
Table 2b: Factors with known influence on ethanol metabolite levels

\begin{tabular}{|c|c|c|c|}
\hline $\begin{array}{l}\text { Direct bio- } \\
\text { markers }\end{array}$ & Potential influencing factor & $\begin{array}{l}\text { Type of } \\
\text { influence }\end{array}$ & Reference \\
\hline \multirow[t]{4}{*}{ EtG in urine } & E. coli, C. sordelli & Decrease & $\begin{array}{l}\text { Helander \& Dahl, 2005; } \\
\text { Baranowksi et al., } 2008\end{array}$ \\
\hline & Reduced kidney function & $\begin{array}{l}\text { Longer } \\
\text { detection }\end{array}$ & $\begin{array}{l}\text { Wurst et al., 2004a; } \\
\text { Hoiseth et al., } 2012 \text {; } \\
\text { Stewart et al., } 2013\end{array}$ \\
\hline & Chloral hydrate & $\begin{array}{l}\text { False } \\
\text { positives }\end{array}$ & Arndt et al., 2009 \\
\hline & Propyl and butyl alcohol & \begin{tabular}{|l|} 
False \\
positives \\
in DRI \\
EtG Assay
\end{tabular} & Arndt et al, 2014b \\
\hline \multirow[t]{2}{*}{ EtS in urine } & Reduced kidney function & $\begin{array}{l}\text { Longer } \\
\text { detection }\end{array}$ & Hoiseth et al., 2012 \\
\hline & $\begin{array}{l}\text { Closed Bottle test (OECD } 301 \text { D) } \\
\text { Manometer Respiratory Test (MRT) }\end{array}$ & $\begin{array}{l}28 \text { days } \\
\text { Stable } \\
\text { detection, } \\
\text { depletion } \\
\text { after } 6 \\
\text { days }\end{array}$ & Halter et al., 2009 \\
\hline \multirow[t]{2}{*}{ FAEEs in hair } & Aggressive alkaline hairsprays & $\begin{array}{l}\text { False } \\
\text { negative }\end{array}$ & \multirow[t]{2}{*}{ Hartwig et al., 2003} \\
\hline & Hairsprays containing ethanol & $\begin{array}{l}\text { False } \\
\text { positives }\end{array}$ & \\
\hline PEth & $\begin{array}{l}\text { Ethanol containing blood samples, } \\
\text { Storage of ethanol blood samples at RT } \\
\text { and }-20^{\circ} \mathrm{C}\end{array}$ & Increase & Aradottir et al 2004 \\
\hline \multirow[t]{4}{*}{ EtG in hair } & Hairspray with EtG & Increase & Sporkert et al. 2012 \\
\hline & Reduced kidney function & Increase & Hoiseth et al. 2013 \\
\hline & Bleaching, hair styling products & $\begin{array}{l}\text { False } \\
\text { negative }\end{array}$ & $\begin{array}{l}\text { Yegles et al., 2004; } \\
\text { Morini et al., } 2010 \\
\text { Kerekes et al., } 2013\end{array}$ \\
\hline & $\begin{array}{l}\text { Commercial hair tonics } \\
\text { containing EtG }\end{array}$ & $\begin{array}{l}\text { Potentially } \\
\text { false }\end{array}$ & Arndt et al, 2014b \\
\hline
\end{tabular}




\begin{tabular}{|l|l|l|l|}
\hline & & positve & \\
\hline & Thermal hair straightening & Decrease & Ettlinger et al, 2014 \\
\hline
\end{tabular}

EtG: Ethyl glucuronide, FAEE: Fatty acid ethyl esters, EtS: Ethyl sulfate, PEth:

Phosphatidylethanol, BMI: body mass index, RT: room ambient temperature, E. coli:

Escherichia coli, C. sordelli: Clostridium sordelli (modified according to Thon et al., 2013) 